\title{
Synthesis and Structural Characterization of Tris(pyrazolyl)hydroaluminate and Tris(pyrazolyl)hydrogallate Lithium Compounds
}

\author{
David Sambade and Gerard Parkin,* \\ Department of Chemistry, \\ Columbia University,
}

New York, New York 10027, USA.

Received $x x x x x x, 2016$.

Abstract: The tris(pyrazolyl)hydroaluminate derivatives, [HAlTp$\left.{ }^{\mathrm{Bu}^{\mathrm{t}}, \mathrm{Me}}\right] \mathrm{Li}$ and $\left\{\left[\mathrm{HAlTp}{ }^{\mathrm{Me}}\right] \mathrm{Li}\right\}_{2}$, have been synthesized via the reactions of $\mathrm{LiAlH}_{4}$ with 3-tert-butyl-5methylpyrazole and 3,5-dimethylpyrazole, respectively, while the tris(pyrazolyl)hydrogallate counterparts, [HGaTp $\left.{ }^{\mathrm{Bu}}, \mathrm{Me}\right] \mathrm{Li}$ and $\left\{\left[\mathrm{HGaTp}{ }^{\mathrm{Me}}\right] \mathrm{Li}\right\}_{2}$, are obtained from the corresponding reactions with $\mathrm{LiGaH}_{4}$. X-ray diffraction studies demonstrate that the 3-tert-butyl-5-methylpyrazolyl derivatives, [HAlTp$\left.{ }^{B u^{t}, \mathrm{Me}}\right] \mathrm{Li}$ and $\left[\mathrm{HGaTp}{ }^{\mathrm{Bu}}{ }^{\mathrm{t}} \mathrm{Me}\right] \mathrm{Li}$, are monomeric with lithium in a trigonal coordination environment, whereas the less sterically demanding 3,5-dimethylpyrazolyl derivatives, $\left\{\left[\mathrm{HAlTp}^{\mathrm{Me}}\right] \mathrm{Li}_{2}\right.$ and $\left\{\left[\mathrm{HGaTp}^{\mathrm{Me} 2}\right] \mathrm{Li}\right\}_{2}$, are dimeric. In addition to the tris(pyrazolyl)hydroaluminate derivative, $\left[\mathrm{HAlTp}^{\mathrm{Bu}}{ }^{\mathrm{t}, \mathrm{Me}}\right] \mathrm{Li}$, the tetrakis derivative, $\left[\left(\mathrm{pz}^{\mathrm{Bu}^{\mathrm{t}}, \mathrm{Me}}\right) \mathrm{AlTp} \mathrm{p}^{\mathrm{Bu}}, \mathrm{Me}\right] \mathrm{Li}$, has also been isolated. X-ray diffraction studies demonstrate that $\left[\left(\mathrm{pz}^{\mathrm{Bu}}, \mathrm{Me}\right) \mathrm{AlTp} \mathrm{pu}^{\mathrm{t}, \mathrm{Me}}\right] \mathrm{Li}$, as obtained from solutions in benzene, exists as a monomer in the solid state with tridentate coordination, whereas crystals obtained from THF exhibit a bidentate coordination mode, which is supplemented by coordination of THF, i.e. $\left[\left(\mathrm{pz}^{\mathrm{Bu}}, \mathrm{Me}\right){ }_{2} \mathrm{AlBp} \mathrm{Bu}^{\mathrm{Bt}}, \mathrm{Me}\right] \mathrm{Li}(\mathrm{THF})$. NMR spectroscopic studies, however, indicate that $\left[\left(\mathrm{pz}^{\mathrm{Bu}}{ }^{\mathrm{t}}, \mathrm{Me}\right) \mathrm{AlTp} \mathrm{pu}^{\mathrm{Bu}, \mathrm{Me}}\right] \mathrm{Li}$ is fluxional in both benzene and THF solutions. 


\section{INTRODUCTION}

The tris(pyrazolyl)hydroborate ligand system, $\left[\mathrm{T}^{\mathrm{R}, \mathrm{R}^{\prime}}\right]$, has found extensive use since it was first introduced by Trofimenko in 1966.1,2 Indeed, we have previously employed tris(pyrazolyl)hydroborate ligands that feature bulky tert-butyl substituents, $\left[\mathrm{Tp}^{\mathrm{Bu}} \mathrm{R}^{\prime} \mathrm{R}^{\prime}\right]$ $\left(\mathrm{R}^{\prime}=\mathrm{H}, \mathrm{Me}, \mathrm{Bu}^{\mathrm{t}}\right)$, to provide a sterically demanding coordination pocket that has allowed isolation of a variety of novel compounds. For example, we have used [T $\mathrm{T}^{\mathrm{Bu}} \mathrm{R}^{\mathrm{t}}$ ] ligands to obtain (i) monomeric alkyl, hydride, hydroxide and fluoride derivatives of $\mathrm{Be}^{3} \mathrm{Mg}^{4,5} \mathrm{Zn},{ }^{6,7}$ and $\mathrm{Cd},{ }^{8}$ and (ii) monomeric monovalent compounds of $\mathrm{Ga}^{9}$ and $\mathrm{In}^{10}$ and their terminal chalcogenido derivatives. However, in contrast to the extensive use of $\left[\mathrm{T}^{\mathrm{R}, \mathrm{R}^{\prime}}\right]$ ligands that feature boron as the bridgehead, the chemistry of the aluminum and gallium counterparts, $\left[\mathrm{HAlT} \mathrm{p}^{\mathrm{R}, \mathrm{R}^{\prime}}\right]$ and $\left[\mathrm{HGaTp} \mathrm{p}^{\mathrm{R}, \mathrm{R}^{\prime}}\right]{ }^{*}$ is almost nonexistent. For example, whereas there are 4876 structurally characterized $\left[T \mathrm{p}^{\mathrm{R}, \mathrm{R}^{\prime}}\right]$ compounds listed in the Cambridge Structural Database (CSD) ${ }^{\mathbf{1 1}}$ there are only three compounds that feature aluminum as the bridgehead, namely [HAlTp $\left.{ }^{\mathrm{Ph}_{2}}\right] \mathrm{Li}(\mathrm{THF}),\left[\mathrm{HAlT}^{\operatorname{Pr}_{2}}{ }_{2} \mathrm{Li}(\mathrm{THF})\right.$ and $\left[\mathrm{HAlTp} \mathrm{Ph}_{2}\right] \mathrm{ZnH},{ }^{12}$ while there are no examples of gallium $\left[\mathrm{HGaTp} \mathrm{p}^{\mathrm{R}, \mathrm{R}^{\prime}}\right]$ derivatives. ${ }^{13}$ Therefore, we report here the synthesis and structural characterization of tris(pyrazolyl)hydroaluminate and gallate derivatives, $\left[\mathrm{HETp}^{\mathrm{Bu}} \mathrm{He}^{\mathrm{t}}\right] \mathrm{Li}$ and $\left\{\left[\mathrm{HETp}^{\mathrm{Me}}\right] \mathrm{Li}\right\}_{2}(\mathrm{E}=\mathrm{Al}, \mathrm{Ga})$.

\section{RESULTS AND DISCUSSION}

\section{Synthesis and Structures of $\left[\mathrm{HAlT} \mathrm{p}^{\mathrm{Bu}, \mathrm{Me}}\right] \mathrm{Li},\left[\left(\mathrm{pz}^{\mathrm{Bu}, \mathrm{Me}}\right) \mathrm{AlT} \mathrm{p}^{\mathrm{Bu} \mathrm{u}^{\mathrm{t}}, \mathrm{Me}}\right] \mathrm{Li}$, and [HGaTp $\left.{ }^{\text {But,Me}}\right]$ Li.}

The reactions between alkali metal borohydrides, $\mathrm{MBH}_{4}(\mathrm{M}=\mathrm{Li}, \mathrm{Na}, \mathrm{K})$, and pyrazoles, $H p z^{R, R^{\prime}}$, have been previously employed to afford an extremely diverse series of

\footnotetext{
* We adopt here the same notation used for the tris(pyrazolyl)borate ligand system (reference $2 \mathrm{a}, \mathrm{b}$ ), with the appropriate modification of including $\mathrm{HAl}$ and $\mathrm{HGa}$ as prefixes to indicate the identity of the linker group.
} 
polypyrazolylborate derivatives, $\left[\mathrm{H}_{x} \mathrm{~B}\left(\mathrm{pz}^{\mathrm{R}, \mathrm{R}^{\prime}}\right){ }_{4-x}\right] \mathrm{M}(x=0,1,2) \cdot{ }^{2 \mathrm{a}, \mathrm{b}}$ As such, polypyrazolylborate ligands are among the most popular in contemporary coordination chemistry. Despite the numerous reports describing the reactivity of $\mathrm{MBH}_{4}$ towards pyrazoles, however, we are aware of only one report concerned with the corresponding reactivity of the aluminum counterparts, $\mathrm{MAlH}_{4}$. Specifically, Winter reported that $\mathrm{LiAlH}_{4}$ reacts with 3,5-diphenylpyrazole and 3,5-diisopropylpyrazole to afford a series of $\left[\mathrm{H}_{x} \mathrm{Al}\left(\mathrm{pz}^{\mathrm{R}_{2}}\right)_{4-x}\right] \operatorname{Li}(\mathrm{THF})_{y}(x=0,1,2)$ derivatives. ${ }^{12,14}$

In view of our aforementioned use of tris(pyrazolyl)borate ligands that feature sterically demanding tert-butyl substituents (e.g. $\left.\left[\mathrm{Tp}^{\mathrm{Bu}}, \mathrm{Me}\right]\right)$ to allow isolation of compounds with novel functionalities, we sought the aluminum counterpart (i.e. $\left.\left[\mathrm{HAlTp}^{\mathrm{Bu}}{ }^{\mathrm{t}} \mathrm{Me}\right]\right)$ on the basis that the different steric and electronic properties of aluminum versus boron could influence the chemistry of the systems. Therefore, given the paucity of [HAlTp $\left.{ }^{R, R^{\prime}}\right] \mathrm{Li}$ derivatives, it is significant that the tris(pyrazolyl)hydroaluminate compound, [HAlTp $\left.\mathrm{pu}^{\mathrm{B}, \mathrm{Me}}\right] \mathrm{Li}(\mathbf{1}-\mathrm{Al})$, may indeed be obtained via the reaction of $\mathrm{LiAlH}_{4}$ with 3-tert-butyl-5-methylpyrazole, as illustrated in Scheme 1.15 The tetrakis derivative, $\left[\left(\mathrm{pz}^{\mathrm{Bu}, \mathrm{Me}}\right) \mathrm{AlTp}{ }^{\mathrm{Bu}}{ }^{\mathrm{t}} \mathrm{Me}\right] \mathrm{Li}$ (2-Al), has also been obtained. Interestingly, [( $\left.\left.\mathrm{pz}^{\mathrm{Bu}^{\mathrm{t}}, \mathrm{Me}}\right) \mathrm{AlTp} \mathrm{p}^{\mathrm{Bu}}{ }^{\mathrm{t}} \mathrm{Me}\right] \mathrm{Li}$ and $\left[\mathrm{HAlTp} \mathrm{p}^{\mathrm{Bu}, \mathrm{Me}}\right] \mathrm{Li}$ may be interconverted. Thus, treatment of $\left[\left(\mathrm{pz}^{\mathrm{Bu}}{ }^{\mathrm{t}}, \mathrm{Me}\right) \mathrm{AlTp} \mathrm{pu}^{\mathrm{Bu}}, \mathrm{Me}\right] \mathrm{Li}$ with $\mathrm{LiAlH}_{4}$ generates $\left[\mathrm{HAlTp}^{\mathrm{Bu} t, \mathrm{Me}}\right] \mathrm{Li}$, while addition of 3-tert-butyl-5-methylpyrazole to the latter affords $\left[\left(\mathrm{pz}^{\mathrm{Bu}} \mathrm{u}^{\mathrm{t}, \mathrm{Me}}\right) \mathrm{AlTp}^{\mathrm{Bu}}, \mathrm{Me}\right] \mathrm{Li}($ Scheme 1). 


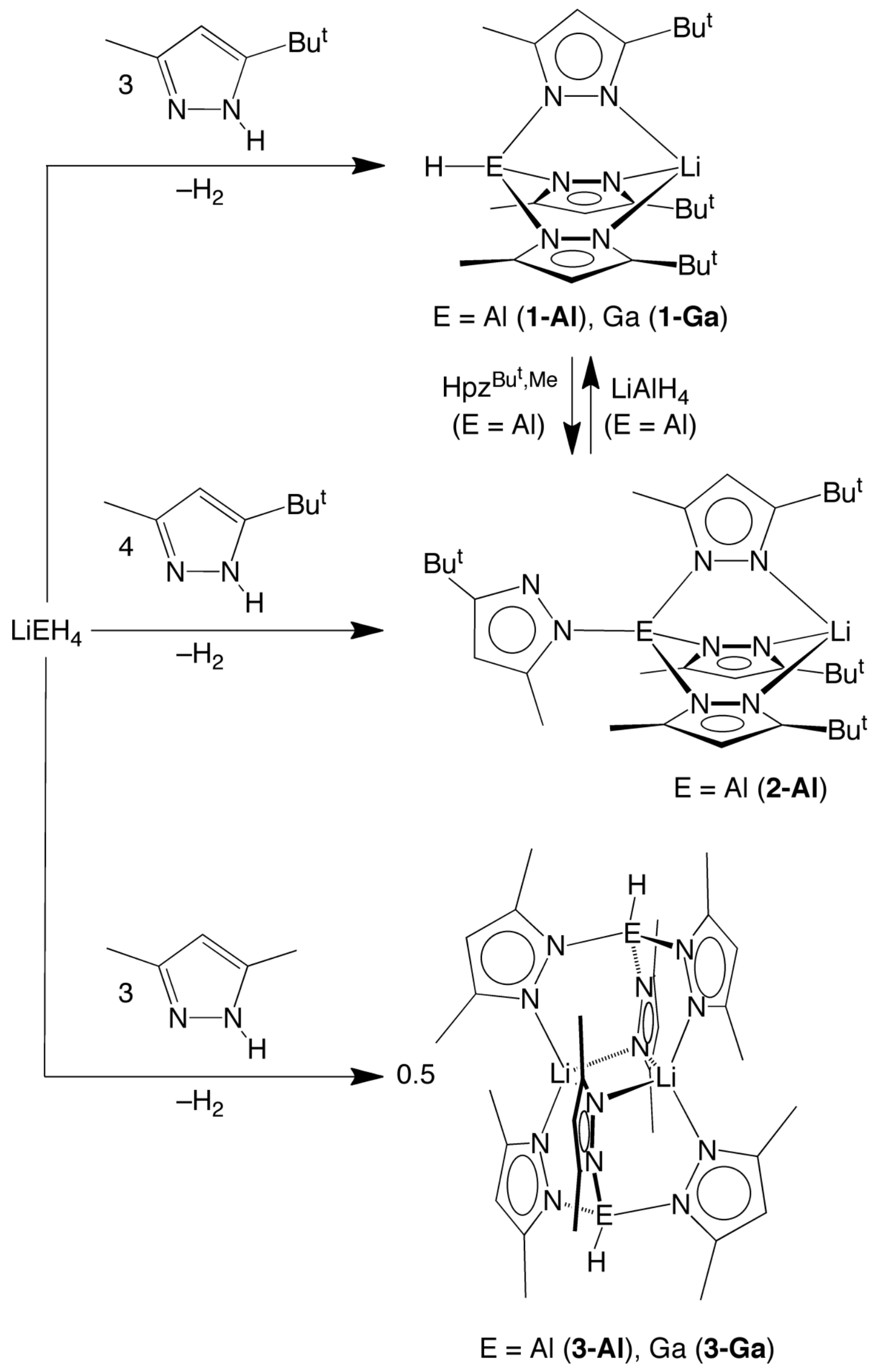




\section{Scheme 1.}

The molecular structures of [HAlTp $\left.\mathrm{pu}^{\mathrm{B}, \mathrm{Me}}\right] \mathrm{Li}$ (Figure 1, Table 1) and $\left[\left(\mathrm{pz}^{\mathrm{Bu}}{ }^{\mathrm{t}}, \mathrm{Me}\right) \mathrm{AlT} \mathrm{p}^{\mathrm{Bu}}, \mathrm{Me}\right] \mathrm{Li}$ (Figure 2, Table 2) have been determined by X-ray diffraction, thereby revealing that both compounds are monomeric, with lithium occupying an uncommon trigonal pyramidal ${ }^{16}$ coordination environment for this element. ${ }^{17}$ As such, the structure of [HAlTp $\left.\mathrm{pu}^{\mathrm{Bu}, \mathrm{Me}}\right] \mathrm{Li}$ represents a notable distinction to the 3,5-

diphenylpyrazolyl and 3,5-diisopropylpyrazolyl counterparts that have been structurally characterized as four-coordinate THF adducts, [HAlTp $\left.\mathrm{ph}_{2}\right] \mathrm{Li}(\mathrm{THF})$ and

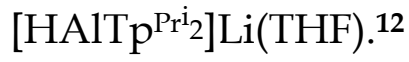

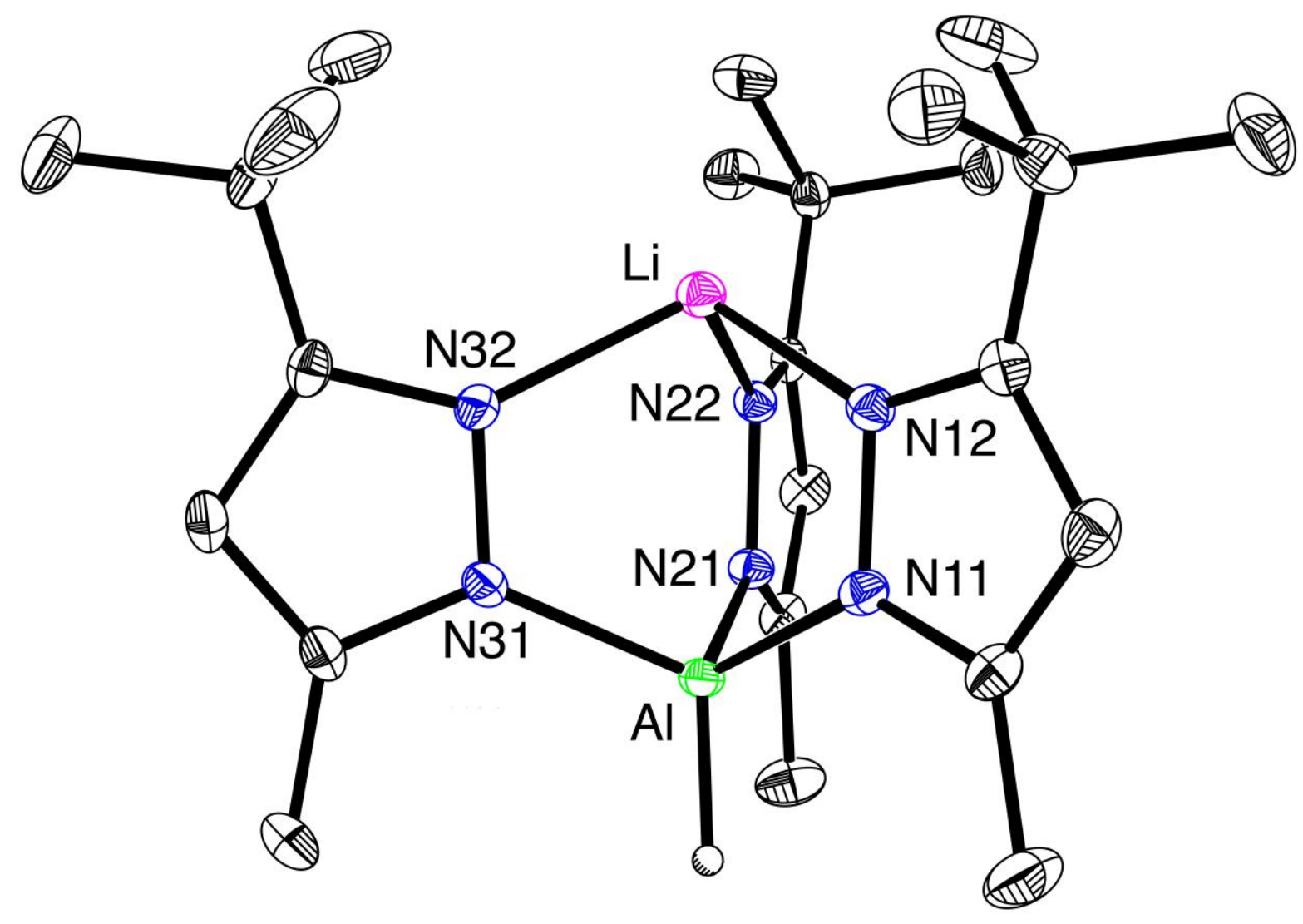

Figure 1. Molecular structure of [HAlTp $\left.{ }^{\mathrm{Bu}}{ }^{\mathrm{t}} \mathrm{Me}\right] \mathrm{Li}$ (1-Al), with displacement ellipsoids depicted at the $30 \%$ probability level. 


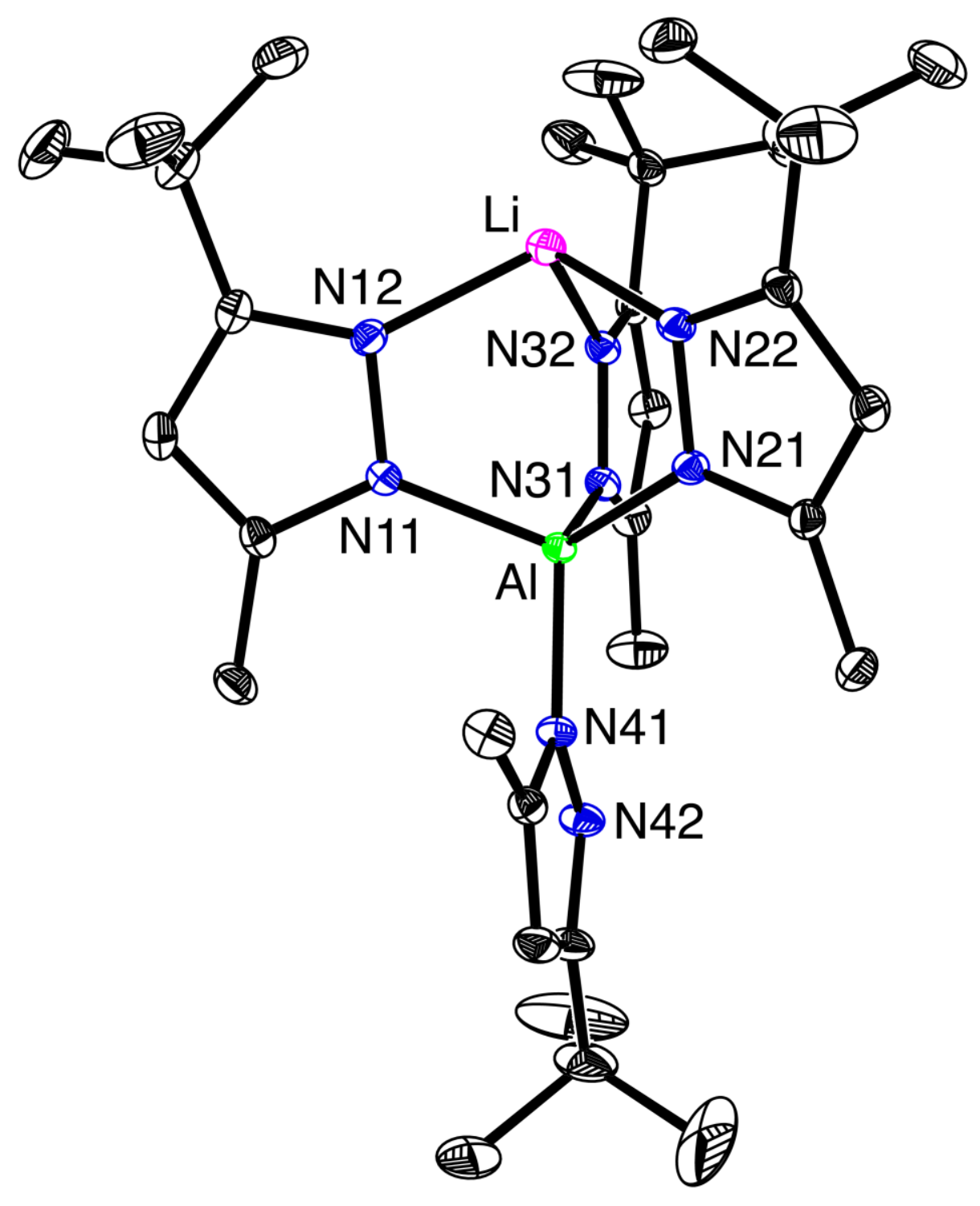

Figure 2. Molecular structure of $\left[\left(\mathrm{pz}^{\mathrm{Bu}}{ }^{\mathrm{t}, \mathrm{Me}}\right) \mathrm{AlTp} \mathrm{p}^{\mathrm{Bu}, \mathrm{Me}}\right] \mathrm{Li}$ (2-Al), with displacement ellipsoids depicted at the $30 \%$ probability level. 
Table 1. Selected metrical data for $\left[\mathrm{HETp}^{\mathrm{Bu}}{ }^{\mathrm{t}} \mathrm{Me}\right] \mathrm{Li}(\mathrm{E}=\mathrm{B}, \mathrm{Al}, \mathrm{Ga})$.

\begin{tabular}{|c|c|c|c|}
\hline & {$\left[\mathbf{T p}^{\mathrm{Bu}}{ }^{\mathrm{t}, \mathrm{Me}}\right] \mathbf{L i} \mathbf{i}^{a}$} & {$\left[\mathrm{HAlT} \mathbf{p}^{\mathrm{Bu}, \mathrm{Me}}\right] \mathrm{Li}$} & {$\left[\mathrm{HGaT} \mathbf{p}^{\mathrm{Bu}{ }^{\mathrm{t}}, \mathrm{Me}}\right] \mathrm{Li}$} \\
\hline$d(\mathrm{Li}-\mathrm{N} 12) / \AA$ & $1.967(3)$ & $1.989(2)$ & $1.982(2)$ \\
\hline$d(\mathrm{Li}-\mathrm{N} 22) / \AA$ & $1.977(3)$ & $2.003(2)$ & $1.982(2)^{b}$ \\
\hline$d(\mathrm{Li}-\mathrm{N} 32) / \AA$ & $1.965(3)$ & $2.006(2)$ & $1.982(2)^{b}$ \\
\hline$d\left(\mathrm{Li}-\mathrm{N}_{\mathrm{av}}\right) / \AA$ & 1.970 & 1.999 & 1.982 \\
\hline$d(\mathrm{E}-\mathrm{N} 11) / \AA$ & $1.553(2)$ & $1.8846(12)$ & $1.9384(12)$ \\
\hline$d(\mathrm{E}-\mathrm{N} 21) / \AA$ & $1.552(2)$ & $1.8757(11)$ & $1.9384(12)^{b}$ \\
\hline$d(\mathrm{E}-\mathrm{N} 31) / \AA$ & $1.5496(19)$ & $1.8840(12)$ & $1.9384(12)^{b}$ \\
\hline$d\left(\mathrm{E}-\mathrm{N}_{\mathrm{av}}\right) / \AA$ & 1.551 & 1.881 & 1.938 \\
\hline$d(\mathrm{E}-\mathrm{H}) / \AA$ & $1.10(2)$ & $1.434(15)$ & $1.45(3)$ \\
\hline$d(\mathrm{E} \cdot \cdots \mathrm{Li}) / \AA$ & $2.833(3)$ & $3.003(2)$ & $3.040(5)$ \\
\hline $\mathrm{N} 12-\mathrm{Li}-\mathrm{N} 22 /^{\circ}$ & $96.52(12)$ & $103.09(11)$ & $104.01(15)$ \\
\hline N12-Li-N32/ ${ }^{\circ}$ & $97.42(12)$ & $100.38(11)$ & $104.01(15)^{b}$ \\
\hline $\mathrm{N} 22-\mathrm{Li}-\mathrm{N} 32 /^{\circ}$ & 99.91(12) & $104.33(11)$ & $104.01(15)^{b}$ \\
\hline $\mathrm{N}-\mathrm{Li}-\mathrm{N}_{\mathrm{av}} /{ }^{\circ}$ & 98.00 & 102.60 & 104.01 \\
\hline N11-E-N21/ ${ }^{\circ}$ & $110.15(12)$ & 105.95(5) & $102.45(4)$ \\
\hline $\mathrm{N} 11-\mathrm{E}-\mathrm{N} 31 /^{\circ}$ & 109.62(12) & $105.81(5)$ & $102.45(4)^{b}$ \\
\hline $\mathrm{N} 21-\mathrm{E}-\mathrm{N} 31 /^{\circ}$ & $108.55(11)$ & $102.85(5)$ & $102.45(4)^{b}$ \\
\hline $\mathrm{N}-\mathrm{E}-\mathrm{N}_{\mathrm{av}} /^{\circ}$ & 109.44 & 104.87 & 102.45 \\
\hline
\end{tabular}

(a) Data taken from reference 16a.

(b) Bond lengths and angles involving symmetry equivalent atoms. 
Table 2. Selected metrical data for $\left[\left(\mathrm{pz}^{\mathrm{Bu}, \mathrm{Me}}\right) \mathrm{AlT} \mathrm{p}^{\mathrm{Bu}^{\mathrm{t}}, \mathrm{Me}}\right] \mathrm{Li}$ and $\left[\left(\mathrm{pz}^{\mathrm{Bu} t, \mathrm{Me}}\right)_{2} \mathrm{AlBp} \mathrm{Bu}^{\mathrm{Bu}, \mathrm{Me}}\right] \operatorname{Li}(\mathrm{THF})$.

\begin{tabular}{|c|c|c|}
\hline & {$\left[\left(\mathrm{pz}^{\mathrm{Bu}, \mathrm{Me}}\right) \mathrm{AlT} \mathbf{p}^{\mathrm{Bu}, \mathrm{Me}}\right] \mathrm{Li}$} & {$\left[\left(\mathrm{pz}^{\mathrm{Bu}}{ }^{\mathrm{t}}, \mathrm{Me}\right){ }_{2} \mathrm{AlB} \mathrm{p}^{\mathrm{Bu}}{ }^{\mathrm{t}}, \mathrm{Me}\right] \operatorname{Li}(\mathrm{THF})$} \\
\hline$d(\mathrm{Li}-\mathrm{N} 12) / \AA$ & $1.985(2)$ & $1.987(5)$ \\
\hline$d(\mathrm{Li}-\mathrm{N} 22) / \AA$ & $1.989(2)$ & $1.976(5)$ \\
\hline$d(\mathrm{Li}-\mathrm{N} 32) / \AA$ & $2.048(2)$ & - \\
\hline$d(\mathrm{Li}-\mathrm{O}) / \AA$ & - & $1.910(5)$ \\
\hline$d(\mathrm{Al}-\mathrm{N} 11) / \AA$ & $1.8822(10)$ & $1.867(2)$ \\
\hline$d(\mathrm{Al}-\mathrm{N} 21) / \AA$ & $1.8830(10)$ & $1.869(2)$ \\
\hline$d(\mathrm{Al}-\mathrm{N} 31) / \AA$ & $1.8626(10)$ & $1.844(2)$ \\
\hline$d(\mathrm{Al}-\mathrm{N} 41) / \AA$ & $1.8356(10)$ & $1.847(2)$ \\
\hline$d(\mathrm{Al} \cdot . . \mathrm{Li}) / \AA$ & $2.954(2)$ & $3.232(4)$ \\
\hline $\mathrm{N} 12-\mathrm{Li}-\mathrm{N} 22 /{ }^{\circ}$ & 101.89(10) & $102.7(2)$ \\
\hline $\mathrm{N} 12-\mathrm{Li}-\mathrm{N} 32 /^{\circ}$ & $102.96(10)$ & - \\
\hline $\mathrm{N} 22-\mathrm{Li}-\mathrm{N} 32{ }^{\circ}$ & 101.64(10) & - \\
\hline $\mathrm{O}-\mathrm{Li}-\mathrm{N} 12 /^{\circ}$ & - & $124.7(2)$ \\
\hline $\mathrm{O}-\mathrm{Li}-\mathrm{N} 22 /^{\circ}$ & - & $120.7(2)$ \\
\hline $\mathrm{N} 11-\mathrm{Al}-\mathrm{N} 21 /^{\circ}$ & $109.83(4)$ & $110.68(9)$ \\
\hline $\mathrm{N} 11-\mathrm{Al}-\mathrm{N} 31{ }^{\circ}$ & $105.34(4)$ & $109.43(9)$ \\
\hline $\mathrm{N} 11-\mathrm{Al}-\mathrm{N} 41 /^{\circ}$ & $107.86(4)$ & $107.62(9)$ \\
\hline $\mathrm{N} 21-\mathrm{Al}-\mathrm{N} 31 /^{\circ}$ & $105.18(4)$ & $110.80(9)$ \\
\hline $\mathrm{N} 21-\mathrm{Al}-\mathrm{N} 41{ }^{\circ}$ & $107.09(4)$ & $106.58(9)$ \\
\hline $\mathrm{N} 31-\mathrm{Al}-\mathrm{N} 41 /^{\circ}$ & $121.25(4)$ & $111.66(9)$ \\
\hline
\end{tabular}

The structure of $\left[\left(\mathrm{pz}^{\mathrm{Bu}, \mathrm{Me}}\right) \mathrm{AlT} \mathrm{p}^{\mathrm{Bu}, \mathrm{Me}}\right] \mathrm{Li}$ is noteworthy because the tetrakis(3,5diphenylpyrazolyl)aluminate counterpart has been structurally characterized as the ionic species, $\left[\left(\mathrm{pz}^{\mathrm{Ph}}\right)_{2} \mathrm{AlTp}^{\mathrm{Ph}} 2\right]\left[\mathrm{Li}(\mathrm{THF})_{4}\right]$, in which the lithium does not coordinate to the 
tetrakis(3,5-diphenylpyrazolyl)aluminate moiety. ${ }^{12}$ Furthermore, although a variety of tetrakis(pyrazolyl)borate derivatives have been reported, the majority are derivatives of the parent pyrazole, and there are no structurally characterized metal complexes that feature substituents in both the 3- and 5-positions.11,18

An interesting spectroscopic feature of $\left[\left(\mathrm{pz}^{\mathrm{Bu}^{\mathrm{t}}, \mathrm{Me}}\right) \mathrm{AlTp} \mathrm{pu}^{\mathrm{B}, \mathrm{Me}}\right] \mathrm{Li}$ is that the compound is fluxional on the NMR timescale, ${ }^{19}$ such that the ${ }^{1} \mathrm{H}$ NMR spectrum reveals only one environment for the pyrazolyl groups at room temperature. However, upon cooling a solution in toluene- $d_{8}$, a 3:1 pattern emerges for the pyrazolyl groups, as illustrated in Figure 3. It is, therefore, evident that the interconversion is facile. ${ }^{\dagger} \mathrm{A}$ possible mechanism for the exchange process involves dissociation of one of the pyrazolyl groups, inversion of the boat-like six-membered ring, and reassociation of the originally uncoordinated pyrazolyl group. Another possibility, which does not require inversion of a six-membered ring, is that the exchange could occur via dissociation of two pyrazolyl arms; such a mechanism would presumably be accompanied by coordination of the arene solvent to stabilize the low coordinate lithium center. ${ }^{20}$

† The chemical shifts of the pyrazolyl groups are slightly temperature dependent and so only approximate rate constant data may be obtained. Nevertheless, values of $\Delta H^{\ddagger}=6.3$ $\pm 0.7 \mathrm{kcal} \mathrm{mol}^{-1}$ and $\Delta S^{\ddagger}=-19 \pm 1$ e.u. may be obtained from the derived rate constant data (where the rate constant is defined for the transfer of the uncoordinated pyrazolyl group to a coordinated pyrazolyl group). 


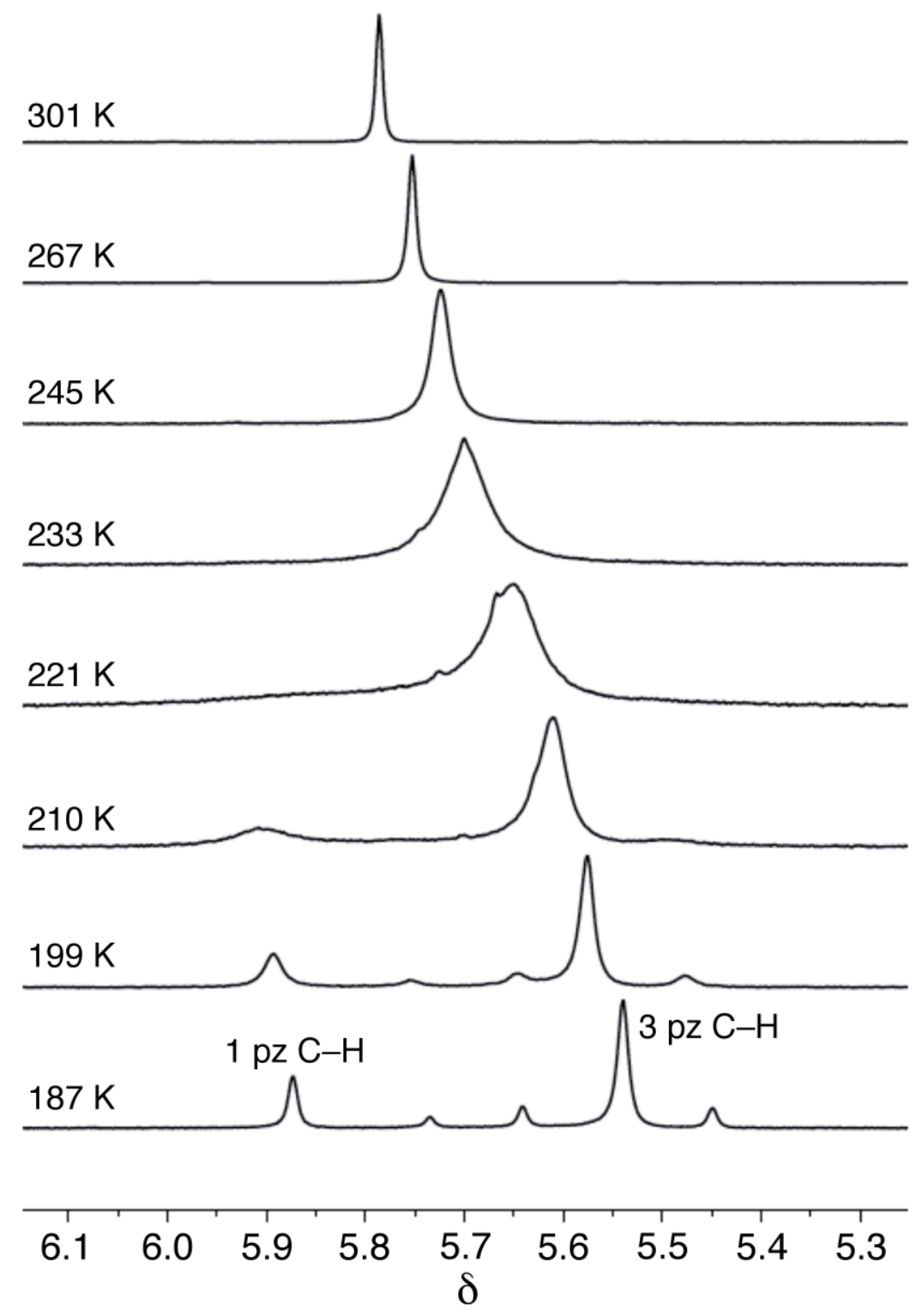

Figure 3. Variable temperature ${ }^{1} \mathrm{H}$ NMR $(400 \mathrm{MHz})$ spectroscopic behavior of the pyrazolyl hydrogen atoms of $\left[\left(\mathrm{pz}^{\mathrm{Bu}}{ }^{\mathrm{t}, \mathrm{Me}}\right) \mathrm{AlT} \mathrm{p}^{\mathrm{Bu}} \mathrm{t}^{\mathrm{t}} \mathrm{Me}\right] \mathrm{Li}$ illustrating exchange of the pyrazolyl groups in toluene- $d_{8}$.

In contrast to the decoalescence observed for $\left[\left(\mathrm{pz}^{\mathrm{Bu}^{\mathrm{t}}, \mathrm{Me}}\right) \mathrm{AlTp} \mathrm{p}^{\mathrm{Bu}, \mathrm{Me}}\right] \mathrm{Li}$ at low temperatures in toluene- $d_{8}$, similar behavior is not observed in THF- $d_{8}$, such that only one set of pyrazolyl groups is observed at temperatures as low as $-96^{\circ} \mathrm{C}$. Of relevance to this observation, X-ray diffraction on crystals obtained from THF, namely $\left[\left(\mathrm{pz}^{\mathrm{Bu}^{\mathrm{t}}, \mathrm{Me}}\right)_{2} \mathrm{AlBp} \mathrm{Bu}^{\mathrm{Bu}}, \mathrm{Me}\right] \mathrm{Li}(\mathrm{THF})(2-\mathrm{Al}-\mathrm{THF})$, demonstrates that THF coordinates to lithium 
and that the tetrakis(pyrazolyl)aluminate ligand coordinates in a bidentate manner (Figure 4). As such, it is evident that THF promotes dissociation of a pyrazolyl group and thereby facilitates the interconversion of pyrazolyl groups. Supporting this suggestion, the 3,5-diphenylpyrazolyl counterpart has been structurally characterized as the ionic species, $\left[\mathrm{Al}\left(\mathrm{pz}^{\mathrm{Ph}}\right)_{4}\right]\left[\mathrm{Li}(\mathrm{THF})_{4}\right] .^{12}$ Thus, coordination of THF to lithium provides a means to promote the fluxionality of $\left[\left(\mathrm{pz}^{\mathrm{Bu}^{\mathrm{t}}, \mathrm{Me}}\right) \mathrm{AlT} \mathrm{p}^{\mathrm{Bu}}, \mathrm{Me}\right] \mathrm{Li}$.

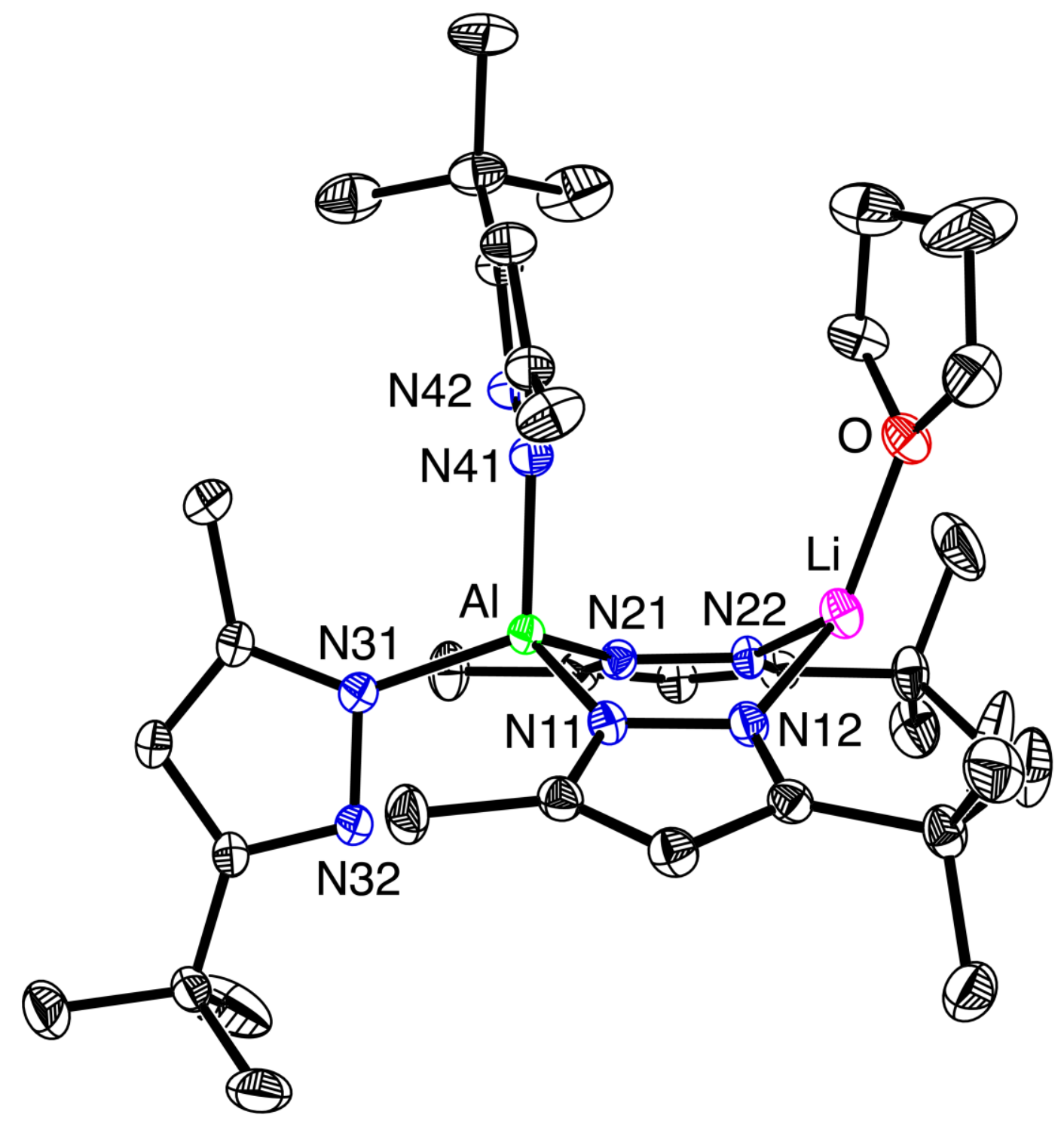

Figure 4. Molecular structure of $\left[\left(\mathrm{pz}^{\mathrm{Bu},, \mathrm{Me}}\right){ }_{2} \mathrm{AlBp}{ }^{\mathrm{Bu}}, \mathrm{Me}\right] \mathrm{Li}(\mathrm{THF})(2-\mathrm{Al}-\mathrm{THF})$, with displacement ellipsoids depicted at the $30 \%$ probability level. 
In addition to the synthesis of [HAlTp $\left.\mathrm{pu}^{\mathrm{Bu}}, \mathrm{Me}\right] \mathrm{Li}$, we have also obtained the gallium counterpart, [HGaTp $\left.{ }^{\mathrm{Bu}}, \mathrm{Me}\right] \mathrm{Li}(\mathbf{1}-\mathrm{Ga})$, by the analogous reaction between $\mathrm{LiGaH}_{4}$ and 3tert-butyl-5-methylpyrazole (Scheme 1). Although [HGaTp $\left.{ }^{\mathrm{Bu}, \mathrm{Me}}\right] \mathrm{Li}$ (Figure 5) is structurally similar to the aluminum derivative, it is of particular interest because there are no examples of structurally characterized $\left[\mathrm{HGaTp} \mathrm{p}^{\mathrm{R}, \mathrm{R}^{\prime}}\right] \mathrm{M}$ derivatives listed in the CSD. ${ }^{11}$ Moreover, Trofimenko has commented that the higher reactivity of Ga-H bonds has made it impossible to obtain $\left[\mathrm{H}_{2} \mathrm{GaBp}^{\mathrm{R}, \mathrm{R}^{\prime}}\right]$ derivatives. ${ }^{2 a}$

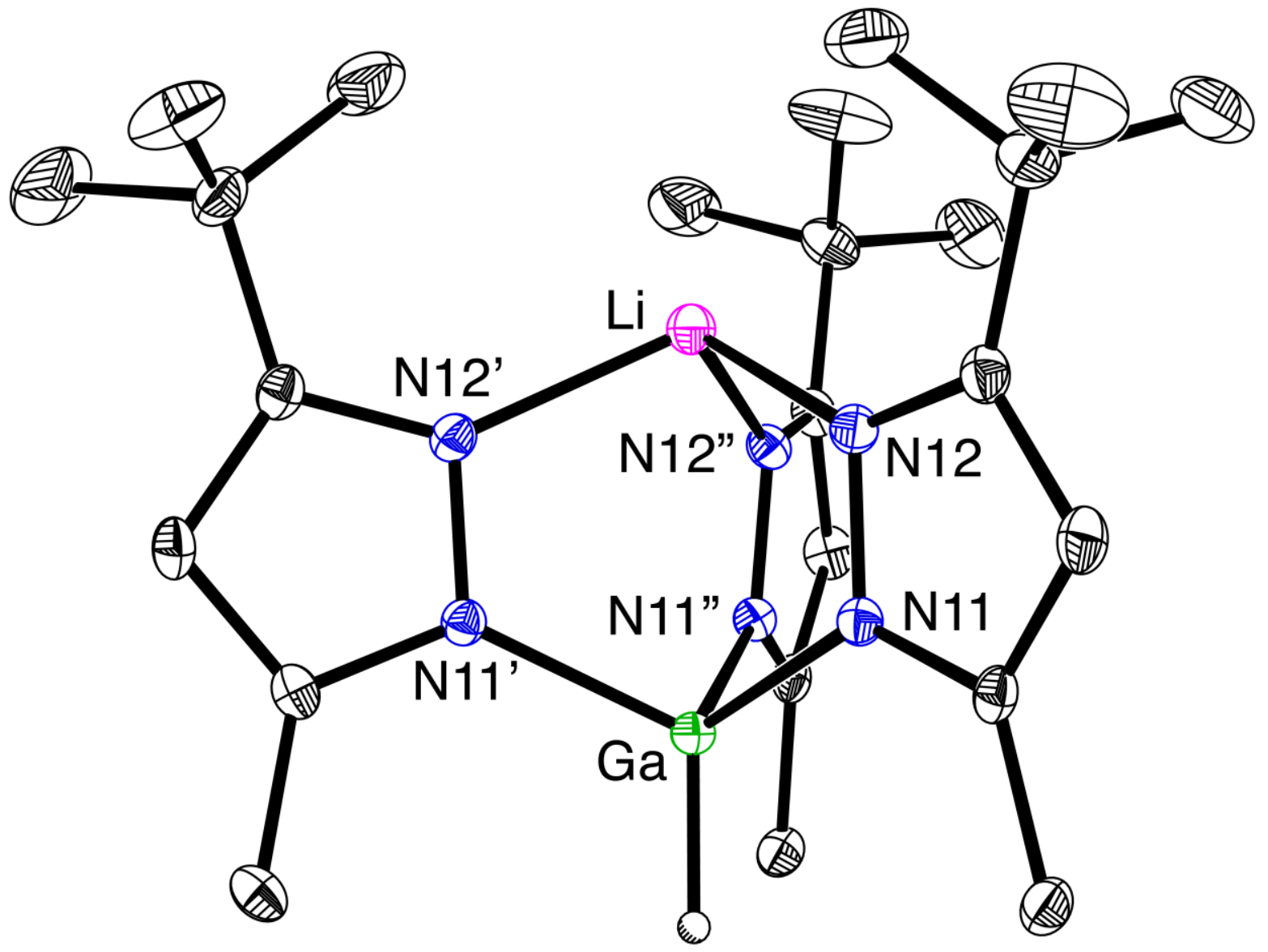

Figure 5. Molecular structure of $\left[\mathrm{HGaTp}{ }^{\mathrm{Bu}}, \mathrm{Me}\right] \mathrm{Li}(\mathbf{1}-\mathrm{Ga})$, with displacement ellipsoids depicted at the $30 \%$ probability level (the molecule resides on a mirror plane). 
Of particular relevance is a comparison of the structures of [HAlTp$\left.{ }^{B u^{\mathrm{t}}, \mathrm{Me}}\right] \mathrm{Li}$ and $\left[\mathrm{HGaTp}{ }^{\mathrm{Bu}}, \mathrm{Me}\right] \mathrm{Li}$ with that of the parent boron derivative, $\left[\mathrm{Tp}^{\mathrm{Bu}, \mathrm{Me}}\right] \mathrm{Li} .{ }^{16}$ Selected metrical data are summarized in Table 1, which demonstrate that the lithium centers of $\left[\mathrm{Tp}^{\mathrm{Bu}, \mathrm{Me}}\right] \mathrm{Li},\left[\mathrm{HAlTp} \mathrm{pu}^{\mathrm{B}, \mathrm{Me}}\right] \mathrm{Li}$ and $\left[\mathrm{HGaTp} \mathrm{Bu}^{\mathrm{B}, \mathrm{Me}}\right] \mathrm{Li}$ have a very similar coordination environment, with the most significant change being a progressive increase in the average $\mathrm{N}-\mathrm{Li}-\mathrm{N}$ bond angle in the sequence $\left[\mathrm{Tp}^{\mathrm{Bu}}, \mathrm{Me}\right] \mathrm{Li}\left(98.0^{\circ}\right)<\left[\mathrm{HAlTp}{ }^{\mathrm{Bu}^{\mathrm{t}}, \mathrm{Me}}\right] \mathrm{Li}$ $\left(102.6^{\circ}\right)<\left[\mathrm{HGaTp}{ }^{\mathrm{Bu}, \mathrm{Me}}\right] \mathrm{Li}\left(104.0^{\circ}\right)$. The origin of the increase between $\left[\mathrm{Tp}^{\mathrm{Bu}}{ }^{\mathrm{t}}, \mathrm{Me}\right] \mathrm{Li}$ and $\left[\mathrm{HAlTp}^{\mathrm{Bu}}, \mathrm{Me}\right] \mathrm{Li}$ is a consequence of the larger covalent radius of aluminum relative to boron (Table 3). ${ }^{21,22}$ The increase in average Al-N bond length compared to the B-N bond length $(0.33 \AA)$, however, is less than that predicted by either the Alvarez $(0.45 \AA)$ or Pykkö $(0.51 \AA)$ values, possibly because of the constraints imposed by the ligand framework. In contrast to the large difference in covalent radii of boron and aluminum, however, gallium and aluminum have very similar sizes (Table 3) due to the scandide contraction, ${ }^{23,24}$ which is the main group counterpart of the lanthanide contraction. As a consequence, the average Al-N (1.881 $\AA$ ) and Ga-N (1.938 $\AA$ ) bond lengths of $\left[\mathrm{HAlTp}^{\mathrm{Bu}}{ }^{\mathrm{t}} \mathrm{Me}\right] \mathrm{Li}$ and $\left[\mathrm{HGaTp}^{\mathrm{Bu} \mathrm{u}^{\mathrm{t}} \mathrm{Me}}\right] \mathrm{Li}$ are similar (Table 1). Nevertheless, despite this similarity, the average $\mathrm{N}-\mathrm{Ga}-\mathrm{N}$ bond angle $\left(102.45^{\circ}\right)$ is slightly smaller than the $\mathrm{N}-\mathrm{Al}-$ $\mathrm{N}$ bond angle $\left(104.87^{\circ}\right)$, and this is reflected by a slightly larger average N-Li-N bond angle for $\left[\mathrm{HGaTp} \mathrm{put}^{\mathrm{Bu}, \mathrm{Me}}\right] \mathrm{Li}($ Table 1$)$.

Table 3. Covalent radii of $\mathrm{B}, \mathrm{Al}$ and $\mathrm{Ga}$.

\begin{tabular}{|l|c|c|}
\hline & $\begin{array}{c}\boldsymbol{r}_{\text {cov/A }} \\
\text { (Alvarez) }^{\mathbf{2 1}}\end{array}$ & $\begin{array}{c}\boldsymbol{r}_{\text {cov/ }} / \AA \\
\text { (Pyykkö) }^{22}\end{array}$ \\
\hline $\mathrm{B}$ & 0.76 & 0.75 \\
\hline $\mathrm{Al}$ & 1.21 & 1.26 \\
\hline $\mathrm{Ga}$ & 1.22 & 1.24 \\
\hline
\end{tabular}




\section{Synthesis and Structure of $\left\{\left[\mathrm{HAlTp} \mathrm{Me}_{2}\right] \mathrm{Li}\right\}_{2}(3-\mathrm{Al})$ and $\left\{\left[\mathrm{HGaTp} \mathrm{Me}_{2}\right] \mathrm{Li}\right\}_{2}(3-\mathrm{Ga})$.}

The importance of employing bulky substituents to isolate the above three-coordinate lithium compounds is highlighted by the fact that replacing the 3-tert-butyl substituent with a methyl group results in a very different type of structure. Thus, the reaction of $\mathrm{LiAlH}_{4}$ with 3,5-dimethylpyrazole affords dinuclear $\left\{\left[\mathrm{HAlTp}{ }^{\mathrm{Me}} 2\right] \mathrm{Li}\right\}_{2}(3-\mathrm{Al})$, while the corresponding reaction of $\mathrm{LiGaH}_{4}$ gives $\left\{\left[\mathrm{HGaTp}^{\mathrm{Me}}\right] \mathrm{Li}_{2}\right.$ (3-Ga) (Scheme 1), both of which have been structurally characterized by X-ray diffraction (Figure 6 and Figure 7). A noteworthy feature of these structures is that two of the pyrazolyl groups of each [HETp ${ }^{\mathrm{Me}_{2}}$ ] ligand coordinate to two different lithium centers, while one of the pyrazolyl groups bridges both lithium centers in an approximately symmetric manner. As would be expected, the Li-N bond lengths involving the bridging pyrazolyl group are slightly longer than the values for the other interactions (Table 4). The occurrence of this bridging coordination mode is presumably driven by the preference of lithium to adopt a tetrahedral geometry, albeit slightly distorted, as illustrated by the magnitude of the four-coordinate $\tau_{4}[\mathrm{Al}, 0.83 ; \mathrm{Ga}, 0.83]$ and $\tau_{4 \delta}[\mathrm{Al}, 0.98 ; \mathrm{Ga}, 0.99]$ geometry indices. ${ }^{25}$

For comparison with $\left\{\left[\mathrm{HAlTp}^{\mathrm{Me}} 2\right] \mathrm{Li}\right\}_{2}$ and $\left\{\left[\mathrm{HGaTp}^{\mathrm{Me}} 2\right] \mathrm{Li}\right\}_{2}$, we have also determined the molecular structure of the boron counterpart, $\left\{\left[\mathrm{Tp}^{\mathrm{Me}} 2\right] \mathrm{Li}\right\}_{2},{ }^{15 a}$ as illustrated in Figure 8. Although this type of bridging motif is not common for $\left[\mathrm{Tp}^{\mathrm{R}, \mathrm{R}^{\prime}}\right] \mathrm{M}$ compounds, it is observed in the ferrocenyl derivative $\{[\mathrm{FcTp}] \mathrm{Li}\}_{2},{ }^{26}$ and the copper compound, $\{[\mathrm{Tp}] \mathrm{Cu}\}_{2} \cdot{ }^{27}$ 


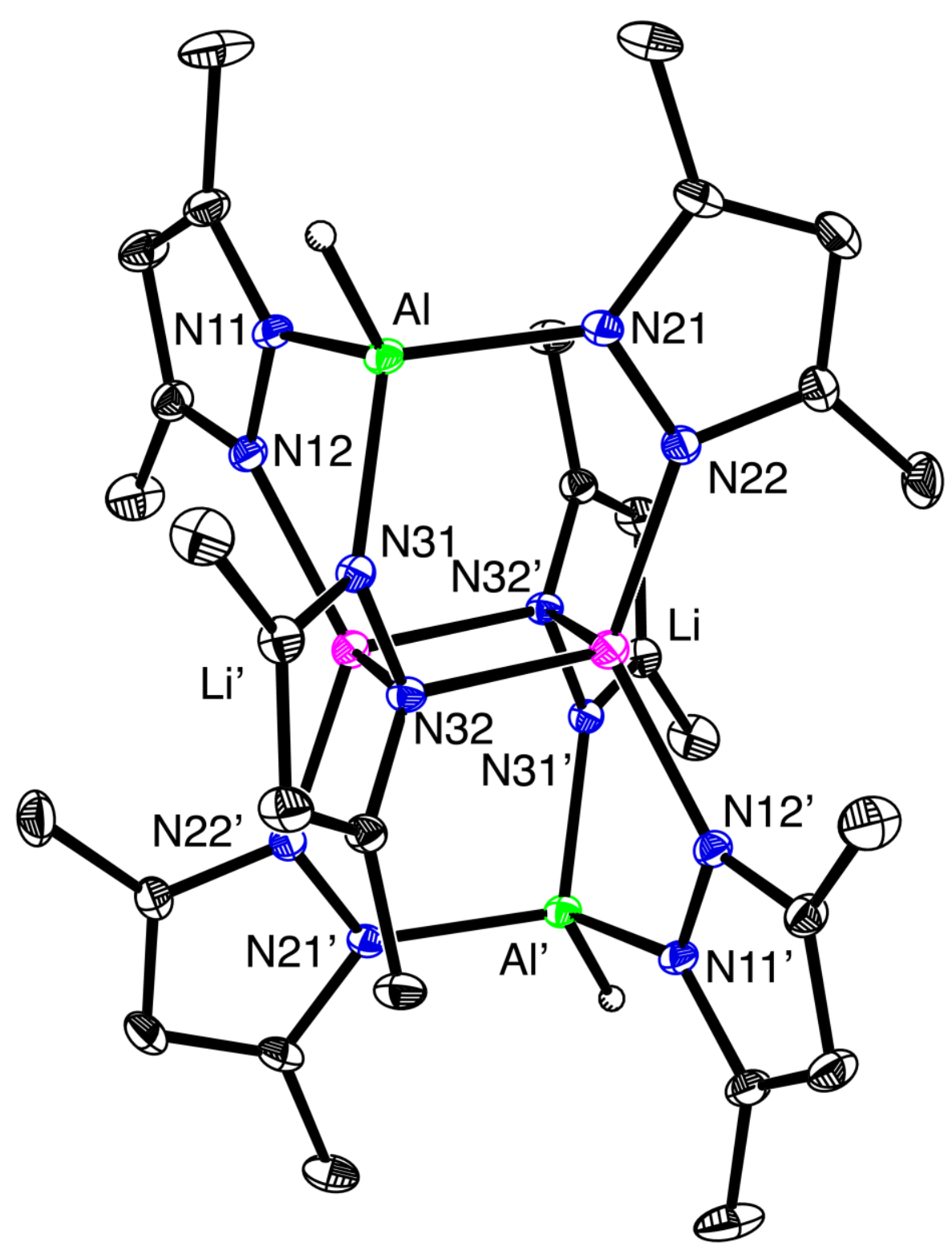

Figure 6. Molecular structure of $\left\{\left[\mathrm{HAlTp}^{\mathrm{Me}}\right] \mathrm{Li}_{2}(3-\mathrm{Al})\right.$, with displacement ellipsoids depicted at the $30 \%$ probability level (the molecule resides on a center of inversion). 


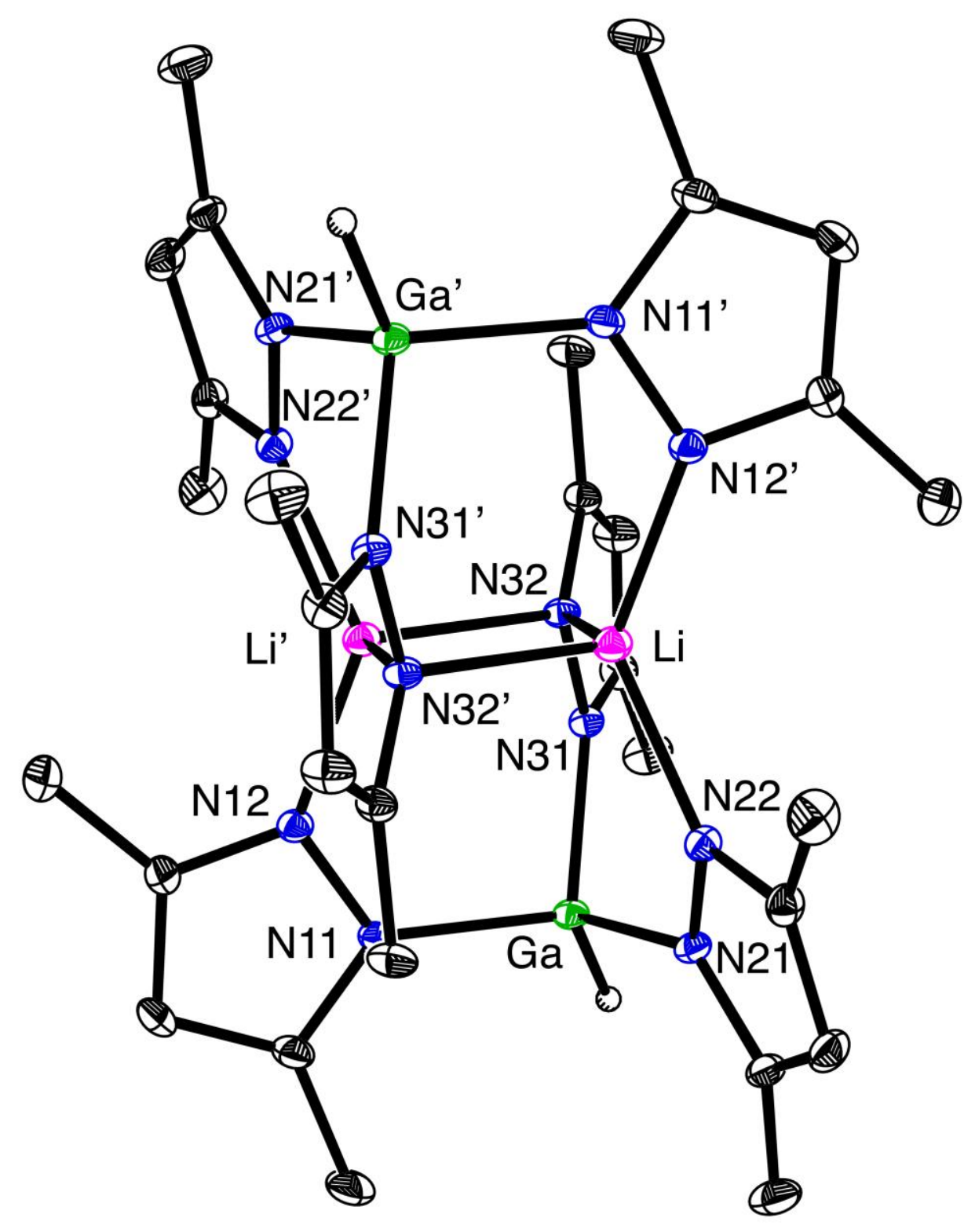

Figure 7. Molecular structure of $\left\{\left[\mathrm{HGaTp}^{\mathrm{Me}}\right]_{\mathrm{Li}}\right\}_{2}(3-\mathrm{Ga})$, with displacement ellipsoids depicted at the $30 \%$ probability level (the molecule resides on a center of inversion). 


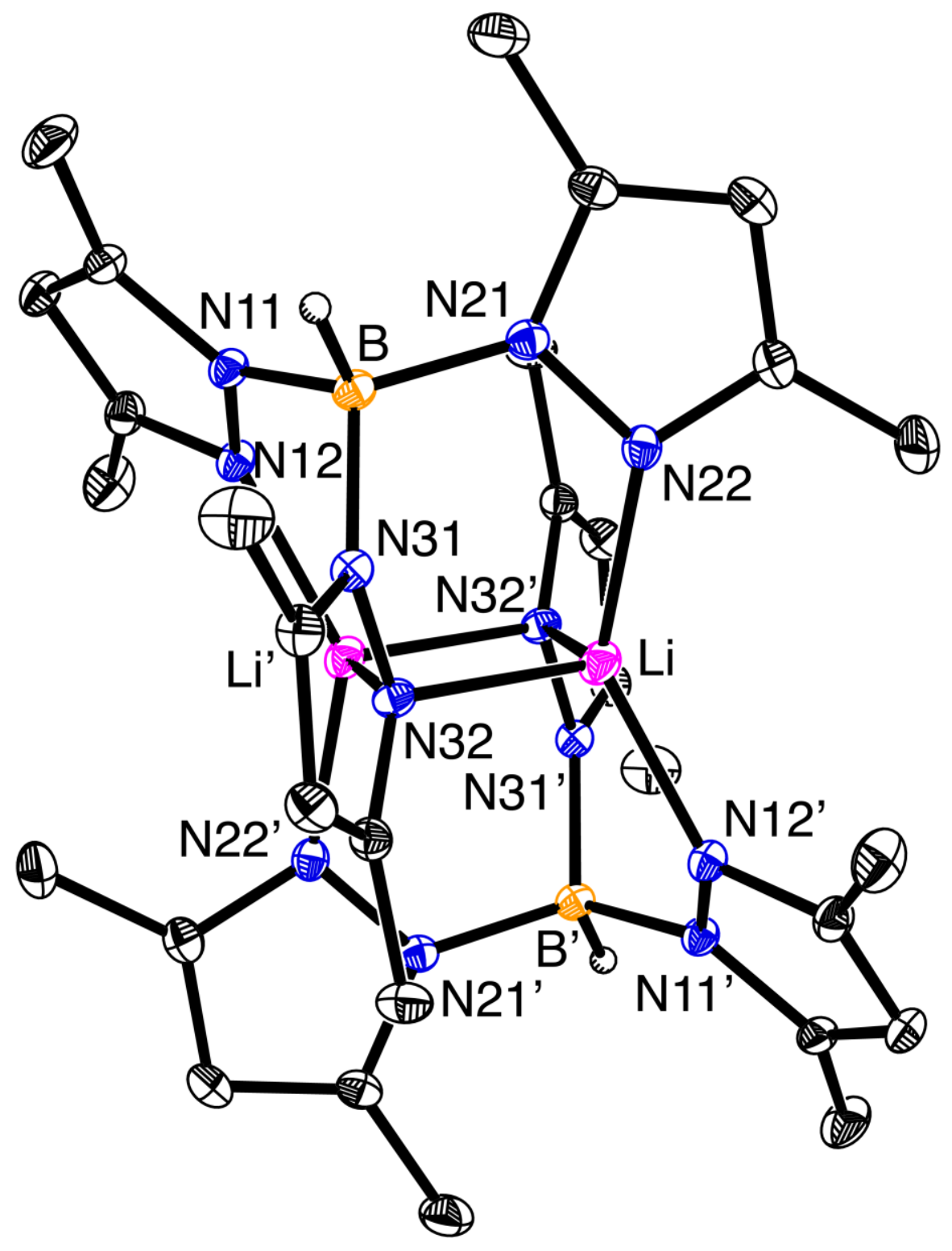

Figure 8. Molecular structure of $\left\{\left[\mathrm{T}^{\mathrm{Me}} 2\right] \mathrm{Li}\right\}_{2}$, with displacement ellipsoids depicted at the $30 \%$ probability level (the molecule resides on a center of inversion). 
Table 4. Selected metrical data for $\left\{\left[\mathrm{HETp}^{\mathrm{Me}}\right]_{\mathrm{Li}}\right\}_{2}(\mathrm{E}=\mathrm{B}, \mathrm{Al}, \mathrm{Ga})$.

\begin{tabular}{|c|c|c|c|}
\hline & $\left\{\left[\mathrm{Tp}^{\mathrm{Me}}{ }_{2}\right] \mathrm{Li}\right\}_{2}$ & $\left\{\left[\mathrm{HAlT} p^{\left.\left.\mathrm{Me}_{2}\right] \mathrm{Li}\right\}_{2}}\right.\right.$ & $\left\{\left[\mathrm{HGaTp} \mathrm{pe}_{2}\right] \mathrm{Li}\right\}_{2}$ \\
\hline$d\left(\mathrm{Li}-\mathrm{N} 12^{\prime}\right) / \AA$ & $1.975(3)$ & $1.991(2)$ & $1.988(3)$ \\
\hline$d(\mathrm{Li}-\mathrm{N} 22) / \AA$ & $1.964(3)$ & $1.986(2)$ & $1.985(3)$ \\
\hline$d(\mathrm{Li}-\mathrm{N} 32) / \AA$ & $2.126(3)$ & $2.164(2)$ & $2.163(3$ \\
\hline$d\left(\mathrm{Li}-\mathrm{N} 32^{\prime}\right) / \AA$ & $2.198(3)$ & $2.201(2)$ & $2.213(3)$ \\
\hline$d(\mathrm{E}-\mathrm{N} 11) / \AA$ & $1.553(2)$ & $1.8888(11)$ & $1.9356(15)$ \\
\hline$d(\mathrm{E}-\mathrm{N} 21) / \AA$ & $1.556(2)$ & $1.8813(11)$ & $1.9302(16)$ \\
\hline$d(\mathrm{E}-\mathrm{N} 31) / \AA$ & $1.536(2)$ & $1.8777(11)$ & $1.9191(14)$ \\
\hline$d(\mathrm{E}-\mathrm{H}) / \AA$ & $1.116(15)$ & $1.493(17)$ & $1.44(3)$ \\
\hline$d(\mathrm{E} \cdot \cdots \mathrm{Li}) / \AA$ & $3.440(3)$ & $3.562(2)$ & $3.616(3)$ \\
\hline N32-Li-N32 ${ }^{\circ}$ & $113.07(12)$ & $111.25(10)$ & $110.82(15)$ \\
\hline Li-N32-Li' ${ }^{\circ}$ & $66.93(12)$ & $68.75(10)$ & 69.17(15) \\
\hline
\end{tabular}

A common feature of $\left\{\left[\mathrm{Tp}^{\mathrm{Me}}\right] \mathrm{Li}\right\}_{2},\left\{\left[\mathrm{HAlTp}{ }^{\mathrm{Me}} 2\right] \mathrm{Li}\right\}_{2}$ and $\left\{\left[\mathrm{HGaTp} \mathrm{Me}_{2}\right] \mathrm{Li}\right\}_{2}$ is the presence of a $\left[\mathrm{Li}_{2} \mathrm{~N}_{2}\right]$ diamond core, as illustrated in Figures 6-8. The metrical data listed in Table 5 show that upon changing the bridging atom from $\mathrm{B}$ to $\mathrm{Al}$ to $\mathrm{Ga}$, the angle at the bridging nitrogen atom increases, while the angle at lithium decreases, with the largest change being between $\left\{\left[\mathrm{Tp}^{\mathrm{Me}}\right][\mathrm{Li}\}_{2}\right.$ and $\left\{\left[\mathrm{HAlTp} \mathrm{Me}_{2}\right] \mathrm{Li}\right\}_{2}$.

Table 5. Selected metrical data for the $\left[\mathrm{Li}_{2} \mathrm{~N}_{2}\right]$ diamond cores of $\{[\mathrm{HETpMe}] \mathrm{Li}\}_{2}(E=B$, $\mathrm{Al}, \mathrm{Ga})$.

\begin{tabular}{|c|c|c|c|}
\hline & $\left.\left\{\left[\mathrm{Tp}^{\mathrm{Me}}\right]_{2}\right] \mathrm{Li}\right\}_{2}$ & $\left\{\left[\mathrm{HAlTp} \mathrm{pe}_{2}\right] \mathrm{Li}\right\}_{2}$ & $\left\{\left[\mathrm{HGaT}^{\mathrm{Me}} \mathrm{p}_{2}\right] \mathrm{Li}\right\}_{2}$ \\
\hline$d(\mathrm{Li}-\mathrm{N}) / \AA$ & $2.126(3)$ & $2.164(2)$ & $2.163(3)$ \\
\hline$d(\mathrm{Li}-\mathrm{N}) / \AA$ & $2.198(3)$ & $2.201(2)$ & $2.213(3)$ \\
\hline $\mathrm{N}-\mathrm{Li}-\mathrm{N} /{ }^{\circ}$ & $113.07(12)$ & $111.25(10)$ & 110.82(15) \\
\hline $\mathrm{Li}-\mathrm{N}-\mathrm{Li} /{ }^{\circ}$ & $66.93(12)$ & $68.75(10)$ & $69.17(15)$ \\
\hline
\end{tabular}


Geometry optimization of $\left\{\left[\mathrm{HET}^{\mathrm{Me}}\right]_{\mathrm{Li}}\right\}_{2}(\mathrm{E}=\mathrm{B}, \mathrm{Al}, \mathrm{Ga})$ using density functional theory (DFT) reproduces well the dinuclear structures (Figure 9), and also indicates that the dimeric forms are thermodynamically favored over the corresponding monomers (Figure 10), as summarized in Table 6.
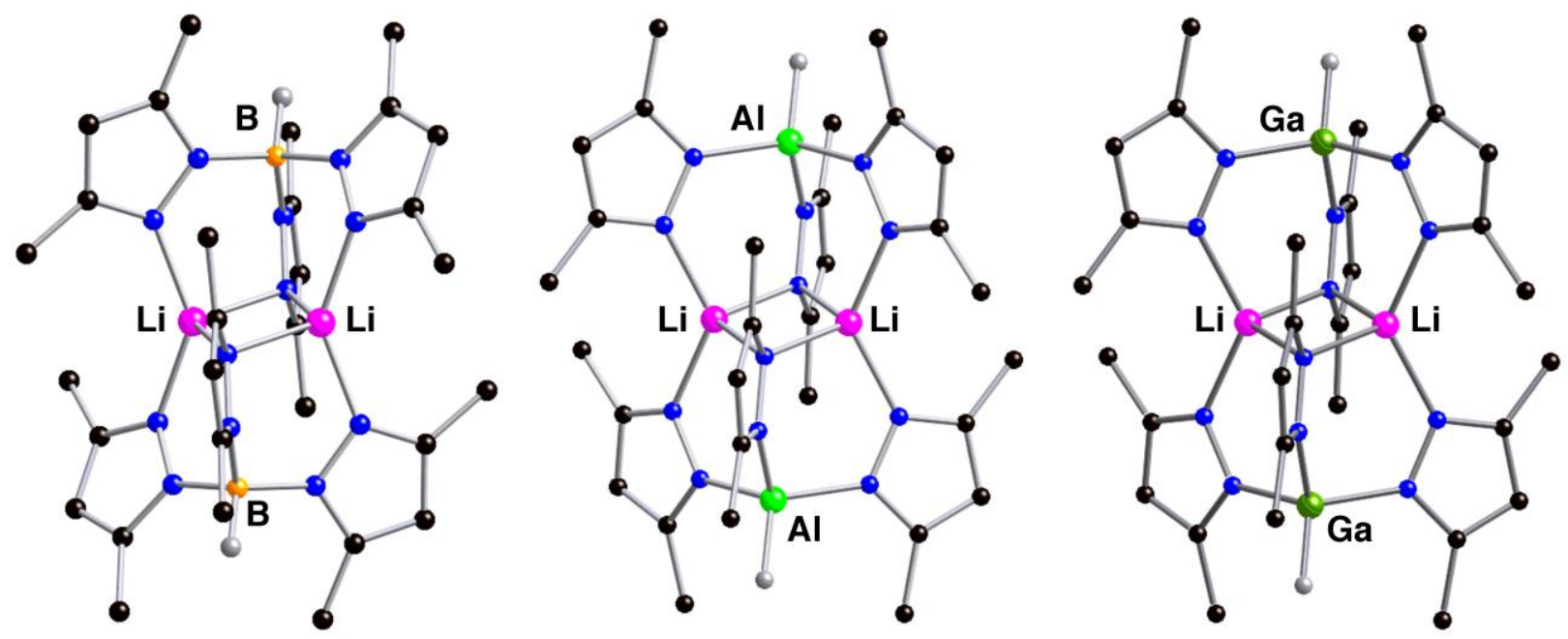

Figure 9. Geometry optimized structures of $\left\{\left[\mathrm{HET}^{\mathrm{Me}} 2\right] \mathrm{Li}\right\}_{2}$.
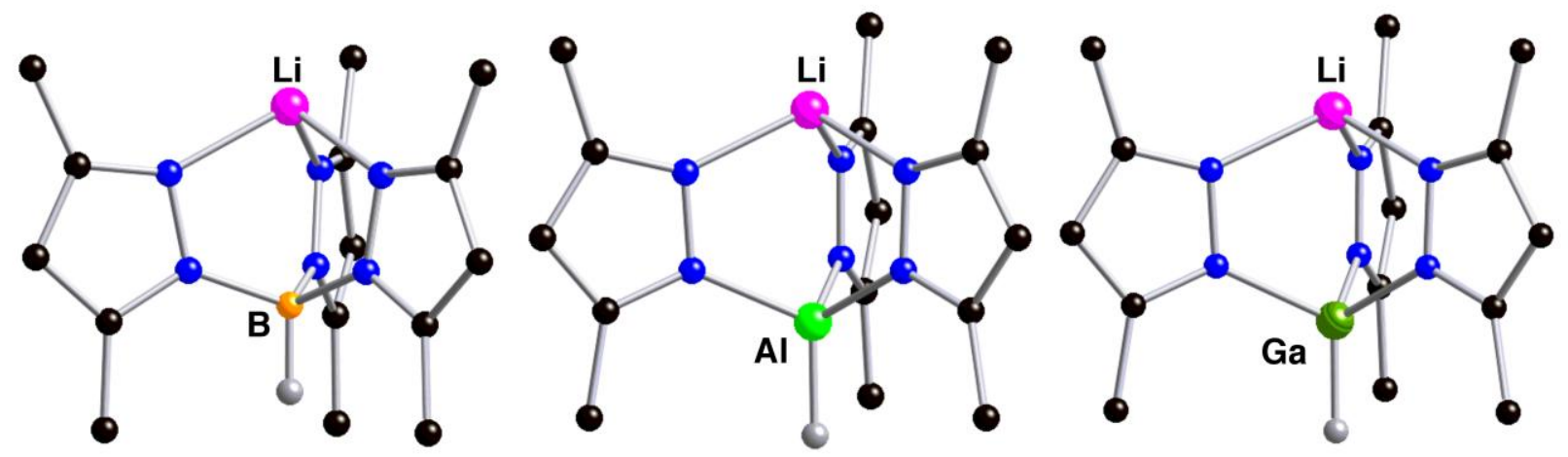

Figure 10. Geometry optimized structures of [HETp $\left.\mathrm{Me}_{2}\right] \mathrm{Li}$. 
Table 6. Energy changes associated with formation of dinuclear structures from the monomers.

\begin{tabular}{|l|c|c|}
\hline & \multicolumn{2}{|c|}{$\Delta E / \mathrm{kcal}_{\text { }}{ }^{-1}{ }^{\text {a }}$} \\
\hline & $\left\{\left[\mathrm{HET}^{\mathrm{Me}}{ }_{2}\right] \mathrm{Li}\right\}_{\mathbf{2}}$ & $\left\{\left[\mathrm{HET}^{\mathrm{Bu}}{ }^{\mathrm{t}, \mathrm{Me}}\right] \mathrm{Li}\right\}_{\mathbf{2}}$ \\
\hline $\mathrm{B}$ & -18.32 & 33.15 \\
\hline $\mathrm{Al}$ & -19.50 & 32.92 \\
\hline $\mathrm{Ga}$ & -17.99 & 35.00 \\
\hline
\end{tabular}

(a) $\Delta E=E\left(\left\{\left[\mathrm{HETp} \mathrm{p}^{\mathrm{R}, \mathrm{Me}}\right] \mathrm{Li}\right\}_{2}\right)-2 E\left(\left[\mathrm{HET} \mathrm{p}^{\mathrm{R}, \mathrm{Me}}\right] \mathrm{Li}\right)$

The ability of [HETp $\left.{ }^{\mathrm{Bu}, \mathrm{Me}}\right] \mathrm{Li}$ to exist as monomers in the solid state, whereas $\left\{\left[\mathrm{HETp}^{\mathrm{Me}} 2\right] \mathrm{Li}\right\}_{2}$ are dimers, is undoubtedly a consequence of the steric demands imposed by the tert-butyl substituents. In this regard, geometry optimization of dinuclear $\left\{\mathrm{HE}\left[\mathrm{Tp}^{\mathrm{Bu}} \mathrm{u}^{\mathrm{t}} \mathrm{Me}\right] \mathrm{Li}\right\}_{2}$ results in a structure in which each pyrazolyl group coordinates to a single lithium center and is therefore devoid of a $\left[\mathrm{Li}_{2} \mathrm{~N}_{2}\right]$ diamond core (Figure 11). As such, the lithium centers of dinuclear $\left\{\left[\mathrm{HETp}^{\mathrm{Bu}}{ }^{\mathrm{t}, \mathrm{Me}}\right] \mathrm{Li}\right\}_{2}$ remain threecoordinate, but with a trigonal planar geometry, rather than the trigonal pyramidal geometry observed in monomeric [HETp $\left.{ }^{\mathrm{Bu}}, \mathrm{Me}\right] \mathrm{Li}$ (Figure 12). As would be expected by the increased steric interactions, the dinuclear structures $\left\{\left[\mathrm{HET} \mathrm{p}^{\mathrm{Bu}}, \mathrm{Me}\right] \mathrm{Li}\right\}_{2}$ are much less stable relative to the monomers than are their $\left\{\left[\mathrm{HETp}^{\mathrm{Me}}\right] \mathrm{Li}_{2}\right\}_{2}$ counterparts (Table 6). The cleavage of the $\left[\mathrm{Li}_{2} \mathrm{~N}_{2}\right]$ core to relieve steric interactions is also reflected by a significant increase in the nonbonded distance between the two lithium centers, for example, from $2.56 \AA$ for $\left\{\left[\mathrm{HAlTp}{ }^{\mathrm{Me}}\right]_{\mathrm{Li}}\right\}_{2}$ to $3.81 \AA$ for $\left\{\left[\mathrm{HAlT} \mathrm{p}^{\mathrm{Bu}}, \mathrm{Me}\right] \mathrm{Li}\right\}_{2}$ (Table 7). The structural differences between $\left\{\left[\mathrm{HETp}^{\mathrm{Me}} 2\right] \mathrm{Li}\right\}_{2}$ and $\left\{\left[\mathrm{HETp}^{\mathrm{Bu}}{ }^{\mathrm{t}} \mathrm{Me}\right] \mathrm{Li}\right\}_{2}$ are very similar to those observed between $\{[\mathrm{Tp}] \mathrm{Cu}\}_{2}$ and $\left\{\left[\mathrm{Tp}^{\mathrm{Me}}\right] \mathrm{Cu}\right\}_{2} .{ }^{27}$ Specifically, whereas one of the pyrazolyl groups of each $[\mathrm{Tp}]$ ligand of $\{[\mathrm{Tp}] \mathrm{Cu}\}_{2}$ bridges in a symmetric manner such that each copper center is four-coordinate, the dimethylpyrazolyl counterpart, 
$\left\{\left[\mathrm{Tp}^{\mathrm{Me}} 2\right] \mathrm{Cu}\right\}_{2}$, does not possess bridging pyrazolyl groups and the copper centers are three-coordinate.

Rather than a 2:1 pattern that would be expected for the pyrazolyl groups, the solution ${ }^{1} \mathrm{H}$ NMR spectra of $\left\{\left[\mathrm{Tp}^{\mathrm{Me}}\right][\mathrm{Li}\}_{2},\left\{\left[\mathrm{HAlT}{ }^{\mathrm{Me}} 2\right] \mathrm{Li}\right\}_{2}\right.$ and $\left\{\left[\mathrm{HGaTp} \mathrm{Me}_{2}\right] \mathrm{Li}\right\}_{2}$ instead exhibit a single set of resonances at room temperature; furthermore, a single set of resonances is observed for $\left\{\left[\mathrm{HGaTp} \mathrm{pe}^{\mathrm{Me}}\right] \mathrm{Li}\right\}_{2}$ at temperatures as low as $-83^{\circ} \mathrm{C}$. A similar observation was reported for the copper compound, $\{[\mathrm{Tp}] \mathrm{Cu}\}_{2}$, at temperatures as low as $-130^{\circ} \mathrm{C} .{ }^{27}$ As such, it is evident that the exchange between bridging and nonbridging pyrazolyl groups is facile in these systems; the exchange could be either intramolecular within the dimer or involve dissociation into a monomer.

Table 7. Nonbonded Li $\cdots$ Li distances $(\AA)$ in geometry optimized $\left\{\left[\mathrm{HETp}^{\mathrm{Me}} 2\right] \mathrm{Li}_{2}\right.$ and $\left\{\left[\mathrm{HETp}^{\mathrm{Bu}}{ }^{\mathrm{t}, \mathrm{Me}}\right] \mathrm{Li}\right\}_{2}$.

\begin{tabular}{|l|c|c|}
\hline & $\left\{\left[\mathrm{HET}^{\mathrm{Me}}\right] \mathbf{L i}\right\}_{\mathbf{2}}$ & $\left\{\left[\mathrm{HET} \mathbf{p}^{\mathrm{Bu}^{\mathrm{t}}, \mathrm{Me}}\right] \mathbf{L i}\right\}_{\mathbf{2}}$ \\
\hline $\mathrm{B}$ & 2.44 & 3.28 \\
\hline $\mathrm{Al}$ & 2.56 & 3.81 \\
\hline $\mathrm{Ga}$ & 2.57 & 3.80 \\
\hline
\end{tabular}
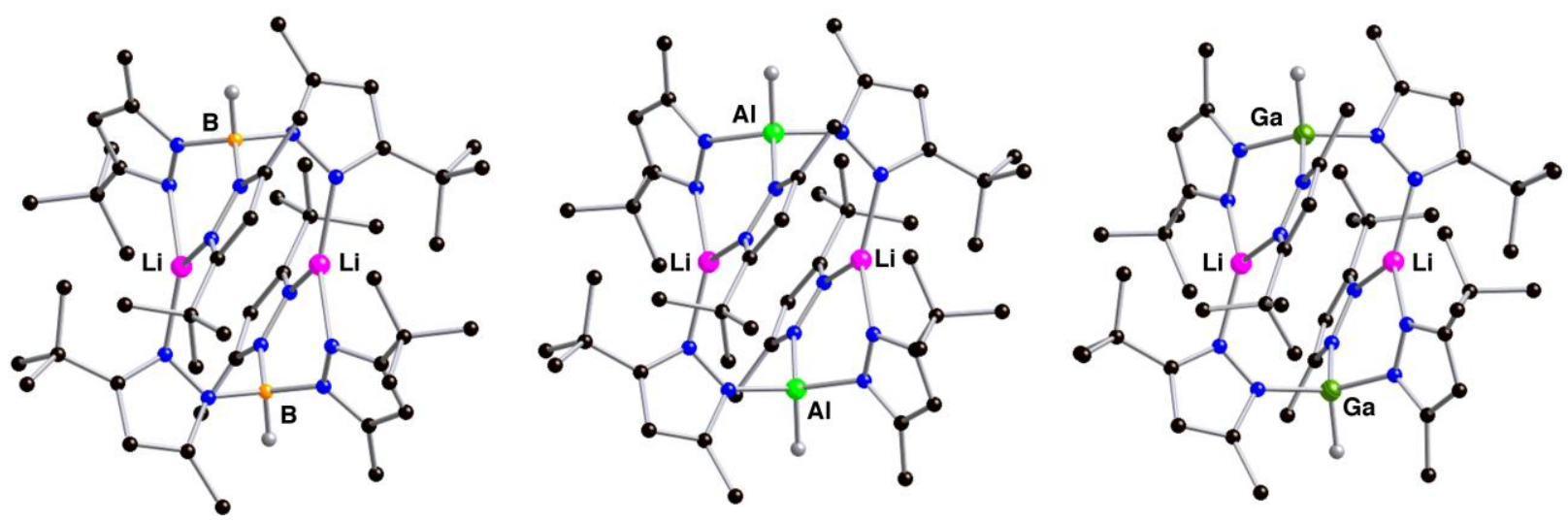

Figure 11. Geometry optimized structures of $\left\{\left[\mathrm{HETp}^{\mathrm{Bu}}, \mathrm{Me}\right] \mathrm{Li}\right\}_{2}$. 


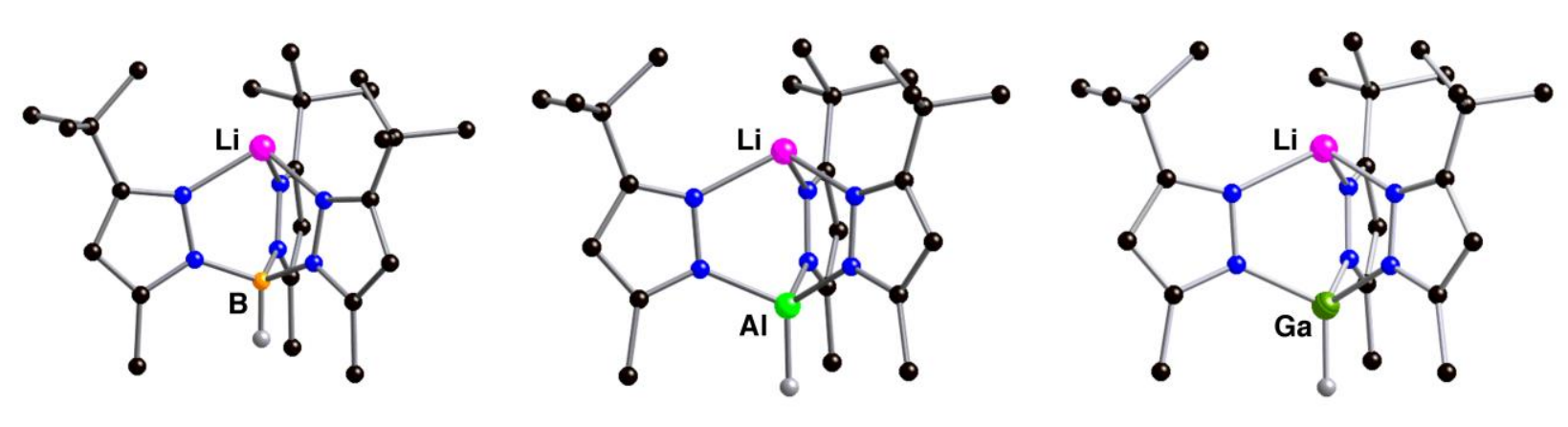

Figure 12. Geometry optimized structures of $\left[\mathrm{HET}^{\mathrm{Bu}}{ }^{\mathrm{t}}, \mathrm{Me}\right] \mathrm{Li}$.

\section{SUMMARY}

In summary, the tris(pyrazolyl)hydroaluminate derivatives, [HAlTp $\left.\mathrm{p}^{\mathrm{Bu}}, \mathrm{Me}\right] \mathrm{Li}$ and $\left\{\left[\mathrm{HAlTp}^{\mathrm{Me}}{ }_{2}\right] \mathrm{Li}\right\}_{2}$, have been synthesized via the reactions of $\mathrm{LiAlH}_{4}$ with 3-tert-butyl-5methylpyrazole and 3,5-dimethylpyrazole, respectively, while the tris(pyrazolyl)hydrogallate counterparts, $\left[\mathrm{HGaTp}^{\mathrm{Bu}}{ }^{\mathrm{t}} \mathrm{Me}\right] \mathrm{Li}$ and $\left\{\left[\mathrm{HGaTp}^{\mathrm{Me}} 2\right] \mathrm{Li}\right\}_{2}$, have been obtained from the corresponding reactions with $\mathrm{LiGaH}_{4}$. X-ray diffraction studies demonstrate that the 3-tert-butyl-5-methylpyrazolyl derivatives, [HAlTp$\left.{ }^{\mathrm{Bu}, \mathrm{Me}}\right] \mathrm{Li}$ and $\left[\mathrm{HGaTp}{ }^{\mathrm{Bu}}, \mathrm{Me}\right] \mathrm{Li}$, are monomeric with trigonally coordinated lithium centers, whereas the less sterically demanding 3,5-dimethylpyrazolyl derivatives, $\left\{\left[\mathrm{HAlTp}^{\mathrm{Me}}\right]_{\mathrm{Li}}\right\}_{2}$ and $\left\{\left[\mathrm{HGaTp} \mathrm{Me}_{2}\right] \mathrm{Li}\right\}_{2}$, are dimeric; specifically, the dimeric compounds feature a [ $\left.\mathrm{Li}_{2} \mathrm{~N}_{2}\right]$ diamond core in which two pyrazolyl groups bridge two lithium centers. In addition to the tris(pyrazolyl)hydroaluminate derivative, [HAlTp $\left.\mathrm{p}^{\mathrm{Bu}, \mathrm{Me}}\right] \mathrm{Li}$, the tetrakis derivative, $\left[\left(\mathrm{pz}^{\mathrm{Bu}}{ }^{\mathrm{t}}, \mathrm{Me}\right) \mathrm{AlTp} \mathrm{pu}^{\mathrm{Bu}, \mathrm{Me}}\right] \mathrm{Li}$, has also been isolated. X-ray diffraction studies demonstrate that $\left[\left(\mathrm{pz}^{\mathrm{Bu}}, \mathrm{Me}\right) \mathrm{AlTp}{ }^{\mathrm{Bu}}, \mathrm{Me}\right] \mathrm{Li}$, as obtained from solutions in benzene, exists as a monomer in the solid state with tridentate coordination of the $\left[\left(\mathrm{pz}^{\mathrm{Bu}}{ }^{\mathrm{t}} \mathrm{Me}\right) \mathrm{AlTp} \mathrm{p}^{\mathrm{Bu}, \mathrm{Me}}\right]$ ligand, whereas crystals obtained from THF exhibit a bidentate coordination mode that is supplemented by coordination of THF, i.e. $\left[\left(\mathrm{pz}^{\mathrm{Bu},, M e}\right){ }_{2} \mathrm{AlBp}{ }^{B u^{t}, M e}\right] \mathrm{Li}(\mathrm{THF}) . \mathrm{NMR}$ spectroscopic studies indicate that $\left[\left(\mathrm{pz}^{\mathrm{Bu}^{\mathrm{t}}, \mathrm{Me}}\right) \mathrm{AlTp} \mathrm{pu}^{\mathrm{Bu}, \mathrm{Me}}\right] \mathrm{Li}$ is fluxional in benzene, toluene and THF solutions; however, although decoalescence is observed in toluene 
solution at low temperature, the compound remains fluxional in THF due to the ability of the THF to promote dissociation of the pyrazolyl groups.

\section{EXPERIMENTAL SECTION}

\section{General Considerations}

All manipulations were performed using a combination of glovebox, high vacuum, and Schlenk techniques under either a nitrogen or argon atmosphere. ${ }^{28}$ Solvents were purified and degassed using standard procedures. NMR spectra were measured on Bruker 300 DRX, Bruker 300 DPX, Bruker 400 Avance III, Bruker 400 Cyber-enabled Avance III, and Bruker 500 DMX spectrometers. ${ }^{1} \mathrm{H}$ NMR spectra are reported in ppm relative to $\mathrm{SiMe}_{4}(\delta=0)$ and were referenced internally with respect to the protio solvent impurity $\left(\delta=7.16\right.$ for $\mathrm{C}_{6} \mathrm{D}_{5} \mathrm{H} ; 7.01$ for $\mathrm{C}_{7} \mathrm{D}_{7} \mathrm{H}$; and 3.58 for $\left.\mathrm{C}_{4} \mathrm{D}_{7} \mathrm{HO}\right) .{ }^{29} \quad{ }^{7 \mathrm{Li}} \mathrm{NMR}$ chemical shifts are reported in ppm relative to $\mathrm{LiCl}$ in $\mathrm{D}_{2} \mathrm{O}(\delta=0.0)^{30}$ and were obtained by using the $\Xi / 100 \%$ value of $38.863797 .31{ }^{27} \mathrm{Al}$ NMR chemical shifts are reported in ppm relative to $\mathrm{Al}\left(\mathrm{NO}_{3}\right)_{3}$ in $\mathrm{D}_{2} \mathrm{O}(\delta=0.0)$ and were obtained by using the $\Xi / 100 \%$ value of 26.056859.31 Sample temperatures in variable temperature NMR spectroscopic experiments were determined by calibration using a methanol standard. ${ }^{32}$ Rates of exchange were measured by using gNMR. ${ }^{33}$ Infrared spectra were recorded on a Perkin Elmer Spectrum Two spectrometer in attenuated total reflectance (ATR) mode, and are reported in reciprocal centimeters $\left(\mathrm{cm}^{-1}\right)$. $\mathrm{LiBH}_{4}($ Strem), 3,5-dimethylpyrazole (Sigma Aldrich) and 3-tert-butyl-5-methylpyrazole (Richman Chemical, Inc.) were obtained commercially and used as received. $\mathrm{LiAlH}_{4}$ (Sigma Aldrich) was purified by extraction into $\mathrm{Et}_{2} \mathrm{O}$, followed by removal of the solvent in vacuo, while $\mathrm{LiGaH}_{4}{ }^{34}$ was obtained via the literature method.

\section{X-ray Structure Determinations}

X-ray diffraction data were collected on a Bruker Apex II diffractometer. Crystal data, data collection and refinement parameters are summarized in Table 8. Structures were 
solved by using direct methods and standard difference map techniques, and were refined by full-matrix least-squares procedures on $F^{2}$ with SHELXTL (Version 2014/7). ${ }^{35}$

\section{Computational Details}

Calculations were carried out using DFT as implemented in the Jaguar 8.9 (release 15) ${ }^{36}$ suite of $a b$ initio quantum chemistry programs. ${ }^{37}$ Geometry optimizations were performed with the B3LYP density functional ${ }^{38}$ using the LACVP** basis set.

\section{Synthesis of $\left[\left(\mathrm{pz}^{\mathrm{Bu}, \mathrm{t}, \mathrm{Me}}\right) \mathrm{AlT} \mathrm{p}^{\mathrm{Bu}}{ }^{\mathrm{t}, \mathrm{Me}}\right] \mathrm{Li}$}

A mixture of 3-tert-butyl-5-methylpyrazole $(497.8 \mathrm{mg}, 3.60 \mathrm{mmol})$ and $\mathrm{LiAlH}_{4}(34.2 \mathrm{mg}$, $0.90 \mathrm{mmol})$ in a glass pressure vessel was treated with $\mathrm{C}_{6} \mathrm{H}_{6}(c a .5 \mathrm{~mL})$ and stirred for 90 minutes at room temperature open to an inert atmosphere. After this period, the mixture was filtered and the solution was lyophilized to give $\left[\left(\mathrm{pz}^{\mathrm{Bu}, \mathrm{Me}}\right) \mathrm{AlTp}{ }^{\mathrm{Bu}}{ }^{\mathrm{t}} \mathrm{Me}\right] \mathrm{Li}$ as a white powder $\left(482.7 \mathrm{mg}\right.$, 92\%). Crystals of $\left[\left(\mathrm{pz}^{\mathrm{Bu}^{\mathrm{t}}, \mathrm{Me}}\right) \mathrm{AlTp}^{\mathrm{Bu}}, \mathrm{Me}\right] \mathrm{Li}$ suitable for X-ray diffraction were obtained from a solution in benzene. ${ }^{1} \mathrm{H}$ NMR $\left(\mathrm{C}_{6} \mathrm{D}_{6}\right): \delta 1.37[\mathrm{~s}, 36 \mathrm{H}$ of $\left.\left\{\mathrm{HC}_{3} \mathrm{~N}_{2}\left(\mathrm{C}_{4} \underline{\mathrm{H}} 9\right)\left(\mathrm{CH}_{3}\right)\right\} \mathrm{Al}\left\{\mathrm{HC}_{3} \mathrm{~N}_{2}\left(\mathrm{C}_{4} \underline{\mathrm{H}} 9\right)\left(\mathrm{CH}_{3}\right)\right\}_{3} \mathrm{Li}\right], 2.14$ [s, $12 \mathrm{H}$ of $\left.\left\{\mathrm{HC}_{3} \mathrm{~N}_{2}\left(\mathrm{C}_{4} \mathrm{H}_{9}\right)\left(\mathrm{C}_{3}\right)\right\} \mathrm{Al}\left\{\mathrm{HC}_{3} \mathrm{~N}_{2}\left(\mathrm{C}_{4} \mathrm{H}_{9}\right)\left(\mathrm{C}_{3}\right)\right\}_{3} \mathrm{Li}\right], 5.83$ [s, $4 \mathrm{H}$ of

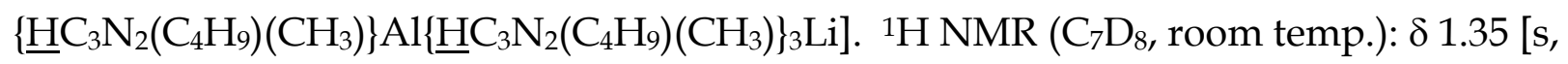
$36 \mathrm{H}$ of $\left.\left\{\mathrm{HC}_{3} \mathrm{~N}_{2}\left(\mathrm{C}_{4} \underline{\mathrm{H}_{9}}\right)\left(\mathrm{CH}_{3}\right)\right\} \mathrm{Al}\left\{\mathrm{HC}_{3} \mathrm{~N}_{2}\left(\mathrm{C}_{4} \underline{\mathrm{H}}_{9}\right)\left(\mathrm{CH}_{3}\right)\right\}_{3} \mathrm{Li}\right], 2.10[\mathrm{~s}, 12 \mathrm{H}$ of $\left\{\mathrm{HC}_{3} \mathrm{~N}_{2}\left(\mathrm{C}_{4} \mathrm{H}_{9}\right)\left(\mathrm{C}_{3}\right)\right\} \mathrm{Al}\left\{\mathrm{HC}_{3} \mathrm{~N}_{2}\left(\mathrm{C}_{4} \mathrm{H}_{9}\right)\left(\mathrm{C}_{3}\right)\right\}_{3} \mathrm{Li}$ ] (partial overlap with solvent), 5.79 [s, $4 \mathrm{H}$ of $\left.\left\{\underline{\mathrm{HC}}_{3} \mathrm{~N}_{2}\left(\mathrm{C}_{4} \mathrm{H}_{9}\right)\left(\mathrm{CH}_{3}\right)\right\} \mathrm{Al}\left\{\underline{\mathrm{H}} \mathrm{C}_{3} \mathrm{~N}_{2}\left(\mathrm{C}_{4} \mathrm{H}_{9}\right)\left(\mathrm{CH}_{3}\right)\right\}_{3} \mathrm{Li}\right] .{ }^{1} \mathrm{H} \mathrm{NMR}\left(\mathrm{C}_{7} \mathrm{D}_{8},-86^{\circ} \mathrm{C}\right): \delta 1.27[\mathrm{~s}$, $27 \mathrm{H}$ of $\left.\left\{\mathrm{HC}_{3} \mathrm{~N}_{2}\left(\mathrm{C}_{4} \mathrm{H}_{9}\right)\left(\mathrm{CH}_{3}\right)\right\} \mathrm{Al}\left\{\mathrm{HC}_{3} \mathrm{~N}_{2}\left(\mathrm{C}_{4} \underline{\mathrm{H}}_{9}\right)\left(\mathrm{CH}_{3}\right)\right\}_{3} \mathrm{Li}\right], 1.59$ [s, $9 \mathrm{H}$ of $\left.\left\{\mathrm{HC}_{3} \mathrm{~N}_{2}\left(\mathrm{C}_{4} \underline{\mathrm{H}}_{9}\right)\left(\mathrm{CH}_{3}\right)\right\} \mathrm{Al}\left\{\mathrm{HC}_{3} \mathrm{~N}_{2}\left(\mathrm{C}_{4} \mathrm{H}_{9}\right)\left(\mathrm{CH}_{3}\right)\right\}_{3} \mathrm{Li}\right], 1.92$ [s, 3H of $\left.\left\{\mathrm{HC}_{3} \mathrm{~N}_{2}\left(\mathrm{C}_{4} \mathrm{H}_{9}\right)\left(\mathrm{C}_{3}\right)\right\} \mathrm{Al}\left\{\mathrm{HC}_{3} \mathrm{~N}_{2}\left(\mathrm{C}_{4} \mathrm{H}_{9}\right)\left(\mathrm{CH}_{3}\right)\right\}_{3} \mathrm{Li}\right], 2.19$ [s, 9H of $\left.\left\{\mathrm{HC}_{3} \mathrm{~N}_{2}\left(\mathrm{C}_{4} \mathrm{H}_{9}\right)\left(\mathrm{CH}_{3}\right)\right\} \mathrm{Al}\left\{\mathrm{HC}_{3} \mathrm{~N}_{2}\left(\mathrm{C}_{4} \mathrm{H}_{9}\right)\left(\mathrm{C}_{3}\right)\right\}_{3} \mathrm{Li}\right], 5.51[\mathrm{~s}, 3 \mathrm{H}$ of

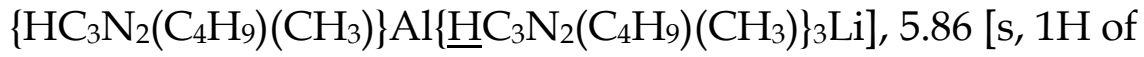

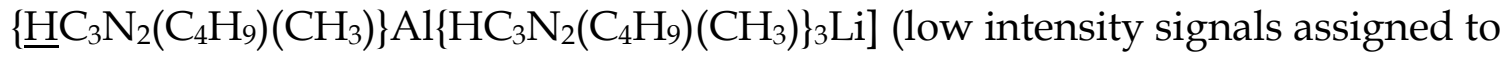
another species at $\delta 1.31,1.38,1.49,1.81,5.43,5.63,5.71$ also appear in the low 
temperature spectrum). ${ }^{1} \mathrm{H}$ NMR (THF-d8, room temp.): $\delta 1.26[\mathrm{~s}, 36 \mathrm{H}$ of $\left.\left\{\mathrm{HC}_{3} \mathrm{~N}_{2}\left(\mathrm{C}_{4} \underline{\mathrm{H}}_{9}\right)\left(\mathrm{CH}_{3}\right)\right\} \mathrm{Al}\left\{\mathrm{HC}_{3} \mathrm{~N}_{2}\left(\mathrm{C}_{4} \underline{\mathrm{H}}_{9}\right)\left(\mathrm{CH}_{3}\right)\right\}_{3} \mathrm{Li}\right], 1.67$ [s, $12 \mathrm{H}$ of $\left.\left\{\mathrm{HC}_{3} \mathrm{~N}_{2}\left(\mathrm{C}_{4} \mathrm{H}_{9}\right)\left(\underline{\mathrm{C}}_{3}\right)\right\} \mathrm{Al}\left\{\mathrm{HC}_{3} \mathrm{~N}_{2}\left(\mathrm{C}_{4} \mathrm{H}_{9}\right)\left(\mathrm{C}_{3}\right)\right\}_{3} \mathrm{Li}\right], 5.82$ [s, $4 \mathrm{H}$ of

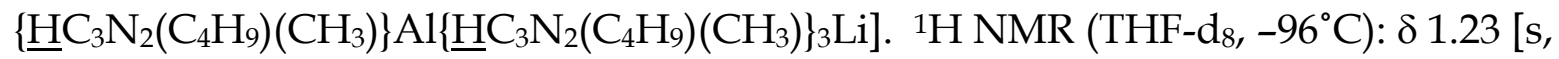
$36 \mathrm{H}$ of $\left.\left\{\mathrm{HC}_{3} \mathrm{~N}_{2}\left(\mathrm{C}_{4} \underline{\mathrm{H}}_{9}\right)\left(\mathrm{CH}_{3}\right)\right\} \operatorname{Al}\left\{\mathrm{HC}_{3} \mathrm{~N}_{2}\left(\mathrm{C}_{4} \underline{\mathrm{H}}_{9}\right)\left(\mathrm{CH}_{3}\right)\right\}_{3} \mathrm{Li}\right], 1.75$ [s, $12 \mathrm{H}$ of $\left.\left\{\mathrm{HC}_{3} \mathrm{~N}_{2}\left(\mathrm{C}_{4} \mathrm{H}_{9}\right)\left(\mathrm{C}_{3}\right)\right\} \mathrm{Al}\left\{\mathrm{HC}_{3} \mathrm{~N}_{2}\left(\mathrm{C}_{4} \mathrm{H}_{9}\right)\left(\mathrm{C}_{3}\right)\right\}_{3} \mathrm{Li}\right], 5.85$ [s, $4 \mathrm{H}$ of

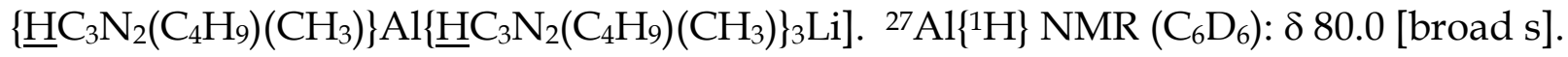
${ }^{7} \operatorname{Li}\left\{{ }^{1} \mathrm{H}\right\} \operatorname{NMR}\left(\mathrm{C}_{6} \mathrm{D}_{6}\right): \delta 3.21[\mathrm{~s}] .{ }^{7} \mathrm{Li}\left\{{ }^{1} \mathrm{H}\right\} \operatorname{NMR}\left(\mathrm{THF}-\mathrm{d}_{8}\right): \delta 1.95$ [s]. Anal. calcd. for $\left[\left(\mathrm{pz}^{\mathrm{Bu}}{ }^{\mathrm{t}} \mathrm{Me}\right) \mathrm{AlTp} \mathrm{Bu}^{\mathrm{B}, \mathrm{Me}}\right] \mathrm{Li}: \mathrm{C}, 66.0 \% ; \mathrm{H}, 9.0 \% ; \mathrm{N}, 19.2 \%$. Found: C, 65.0\%; H, 9.2\%; N, 18.8\%. IR (cm-1): 3164 (m), 3127 (m), 3088 (m), 3016 (m), 2962 (s), 2925 (s), 2859 (m), 2779 (m), $2725(\mathrm{w}), 1574$ (m), 1480 (m), 1299 (s), 1018 (s), 859 (br, m), 779 (s), 697 (m).

\section{Synthesis of [HAlT $\left.{ }^{\mathrm{Bu}^{\mathrm{t}}, \mathrm{Me}}\right] \mathrm{Li}$}

A mixture of 3-tert-butyl-5-methylpyrazole $(500.2 \mathrm{mg}, 3.62 \mathrm{mmol})$ and $\mathrm{LiAlH}_{4}(69.0 \mathrm{mg}$, $1.82 \mathrm{mmol})^{\ddagger}$ in a glass pressure vessel was treated with $\mathrm{C}_{6} \mathrm{H}_{6}(c a .7 \mathrm{~mL})$ and stirred for 1 hour at room temperature open to an inert atmosphere. The mixture was filtered and lyophilized to afford [HAlTp $\left.\mathrm{Bu}^{\mathrm{t}, \mathrm{Me}}\right] \mathrm{Li}$ as a white powder $(528.0 \mathrm{mg}, 98 \%)$. Crystals of $\left[\mathrm{HAlTp}^{\mathrm{Bu}}{ }^{\mathrm{t}} \mathrm{Me}\right] \mathrm{Li}$ suitable for X-ray diffraction were obtained from a solution in benzene.

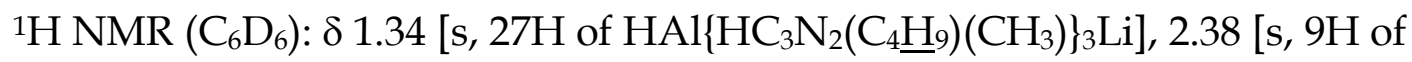
$\left.\mathrm{HAl}\left\{\mathrm{HC}_{3} \mathrm{~N}_{2}\left(\mathrm{C}_{4} \mathrm{H}_{9}\right)\left(\mathrm{C}_{3}\right)\right\}_{3} \mathrm{Li}\right], 5.77$ [s, $3 \mathrm{H}$ of $\left.\mathrm{HAl}\left\{\underline{\mathrm{HC}}_{3} \mathrm{~N}_{2}\left(\mathrm{C}_{4} \mathrm{H}_{9}\right)\left(\mathrm{CH}_{3}\right)\right\}_{3} \mathrm{Li}\right] .{ }^{7 \mathrm{Li}}\left\{{ }^{1} \mathrm{H}\right\} \mathrm{NMR}$ $\left(\mathrm{C}_{6} \mathrm{D}_{6}\right): \delta 3.25$ [s]. ${ }^{27} \mathrm{Al}\left\{{ }^{1} \mathrm{H}\right\} \mathrm{NMR}\left(\mathrm{C}_{6} \mathrm{D}_{6}\right): \delta 97$ [broad s]. Anal. calcd. for [HAlTp $\left.{ }^{\mathrm{Bu}}, \mathrm{Me}\right] \mathrm{Li}$ : C, 64.6\%; H, 9.0\%; N, 18.8\%. Found: C, 64.4\%; H, 9.3\%; N, 18.8\%. IR ( $\left.\mathrm{cm}^{-1}\right): 3092(\mathrm{w})$, 2956 (m), 2862 (w), 1870 (m), 1534 (m), 1481 (w), $1460(\mathrm{~m}), 1435$ (w), 1363 (w), 1354 (w), $1345(w), 1330(w), 1299(w), 1237(w), 1114(s), 1019(m), 1010(m), 834(w), 777(s), 729$ (m), $705(\mathrm{~m}), 669(\mathrm{~s}), 655(\mathrm{~s}), 572(\mathrm{w}), 508(\mathrm{~s}), 455(\mathrm{~s})$.

‡ An excess of $\mathrm{LiAlH}_{4}$ is employed to minimize the formation of $\left[\left(\mathrm{pz}^{\mathrm{Bu}}, \mathrm{Me}\right) \mathrm{AlTp} \mathrm{pu}^{\mathrm{Bu}}, \mathrm{Me}\right] \mathrm{Li}$. See text. 


\section{Interconversion of $\left[\mathrm{HAlT} \mathrm{p}^{\mathrm{Bu}, \mathrm{Me}}\right] \mathrm{Li}$ and $\left[\left(\mathrm{pz}^{\mathrm{Bu}}{ }^{\mathrm{t}, \mathrm{Me}}\right) \mathrm{AlT} \mathrm{p}^{\mathrm{Bu}}, \mathrm{Me}\right] \mathrm{Li}$}

(a) 3-tert-butyl-5-methylpyrazole $(15.5 \mathrm{mg}, 0.11 \mathrm{mmol})$ was treated with a solution of $\left[\mathrm{HAlTp}^{\mathrm{Bu}} \mathrm{u}^{\mathrm{t}} \mathrm{Me}\right] \mathrm{Li}(50.1 \mathrm{mg}, 0.11 \mathrm{mmol})$ in $\mathrm{C}_{6} \mathrm{D}_{6}(c a .0 .7 \mathrm{ml})$ in an NMR tube equipped with a J-Young valve. The sample was monitored by ${ }^{1} \mathrm{H}$ NMR spectroscopy, thereby demonstrating the formation of $\left[\left(\mathrm{pz}^{\mathrm{Bu}}{ }^{\mathrm{t}, \mathrm{Me}}\right) \mathrm{AlT} \mathrm{p}^{\mathrm{Bu}}, \mathrm{Me}\right] \mathrm{Li}$ over a period of 90 minutes at $100^{\circ} \mathrm{C}$.

(b) $\mathrm{LiAlH}_{4}(3.8 \mathrm{mg}, 0.10 \mathrm{mmol})$ was treated with a solution of $\left[\left(\mathrm{pz}^{\mathrm{Bu}, \mathrm{Me}}\right) \mathrm{AlT} \mathrm{p}^{\mathrm{Bu}, \mathrm{Me}}\right] \mathrm{Li}$ $(96.0 \mathrm{mg}, 0.16 \mathrm{mmol})$ in $\mathrm{C}_{6} \mathrm{D}_{6}(c a .0 .7 \mathrm{ml})$ in an NMR tube equipped with a J-Young valve. The sample was monitored by ${ }^{1} \mathrm{H}$ NMR spectroscopy, thereby demonstrating the formation of $\left[\mathrm{HAlT} \mathrm{p}^{\mathrm{Bu}}{ }^{\mathrm{t}} \mathrm{Me}\right] \mathrm{Li}$ over a period of 70 minutes at $100^{\circ} \mathrm{C}$.

\section{Synthesis of $\left[\mathrm{HGaTp} \mathrm{pu}^{\mathrm{Bu}, \mathrm{Me}] \mathrm{Li}}\right.$}

A mixture of 3-tert-butyl-5-methylpyrazole $(159.8 \mathrm{mg}, 1.16 \mathrm{mmol})$ and $\mathrm{LiGaH}_{4}(31.3 \mathrm{mg}$, $0.39 \mathrm{mmol})$ in a glass pressure vessel was treated with benzene (ca. $2 \mathrm{~mL}$ ) and stirred for 2.5 hours at room temperature open to an inert atmosphere, over which period evolution of $\mathrm{H}_{2}$ was observed. The vessel was sealed and the mixture was heated with stirring at $100^{\circ} \mathrm{C}$ for 18 hours. After this period, the mixture was filtered and lyophilized to afford [HGaTp $\left.\mathrm{Hu}^{\mathrm{t}, \mathrm{Me}}\right] \mathrm{Li}$ as a white powder $(154.9 \mathrm{mg}, 83 \%)$. Crystals of $\left[\mathrm{HGaTp}^{\mathrm{Bu}}{ }^{\mathrm{t}} \mathrm{Me}\right] \mathrm{Li}$ suitable for X-ray diffraction were obtained from a solution in benzene. ${ }^{1} \mathrm{H}$ NMR $\left(\mathrm{C}_{6} \mathrm{D}_{6}\right): \delta 1.36$ [s, $27 \mathrm{H}$ of $\left.\mathrm{HGa}\left\{\mathrm{HC}_{3} \mathrm{~N}_{2}\left(\mathrm{C}_{4} \underline{\mathrm{H}}_{9}\right)\left(\mathrm{CH}_{3}\right)\right\}_{3} \mathrm{Li}\right], 2.26[\mathrm{~s}, 9 \mathrm{H}$ of $\left.\mathrm{HGa}\left\{\mathrm{HC}_{3} \mathrm{~N}_{2}\left(\mathrm{C}_{4} \mathrm{H}_{9}\right)\left(\mathrm{CH}_{3}\right)\right\}_{3} \mathrm{Li}\right], 5.80$ [s, 3H of $\left.\mathrm{HGa}\left\{\underline{\mathrm{HC}}_{3} \mathrm{~N}_{2}\left(\mathrm{C}_{4} \mathrm{H}_{9}\right)\left(\mathrm{CH}_{3}\right)\right\}_{3} \mathrm{Li}\right] .{ }^{7} \mathrm{Li}\left\{{ }^{1} \mathrm{H}\right\} \mathrm{NMR}$ $\left(\mathrm{C}_{6} \mathrm{D}_{6}\right): \delta 3.33[\mathrm{~s}]$. Anal. calcd. for [HGaTp $\left.{ }^{\mathrm{Bu}}{ }^{\mathrm{t}}, \mathrm{Me}\right] \mathrm{Li}: \mathrm{C}, 58.9 \% ; \mathrm{H}, 8.2 \% ; \mathrm{N}, 17.2 \%$. Found:

C, 58.6\%; H, 8.2\%; N, 17.4\%. IR (cm-1): $3164(\mathrm{~m}), 3127$ (m), 3088 (m), 3017 (m), 2960 (s), 2926 (m), 2861 (m), 1971 (w), 1699 (br, w), 1230 (m), 1019 (s), 781 (s), 623 (s), 507 (s). 


\section{Synthesis of $\left\{\left[\mathrm{HAlTp} \mathrm{Me}_{2}\right] \mathrm{Li}\right\}_{2}$}

A solution of 3,5-dimethylpyrazole $(126.1 \mathrm{mg}, 1.31 \mathrm{mmol})$ in $\mathrm{C}_{6} \mathrm{H}_{6}(\mathrm{ca} .5 \mathrm{~mL})$ was added via cannula to a stirred suspension of $\mathrm{LiAlH}_{4}(16.7 \mathrm{mg}, 0.44 \mathrm{mmol})$ in $\mathrm{C}_{6} \mathrm{H}_{6}(c a .5 \mathrm{~mL})$ in a glass pressure vessel. The reaction mixture was heated at $60^{\circ} \mathrm{C}$ for two days, over which period a white solid was deposited. After cooling to room temperature, the volatile components were removed in vacuo and the resulting solid was washed with pentane (ca. $2 \times 1 \mathrm{~mL})$ and dried in vacuo to afford $\left\{\left[\mathrm{HAlTp} \mathrm{Me}^{\mathrm{M}}\right] \mathrm{Li}\right\}_{2}$ as a white solid (97.3 $\mathrm{mg}, 73 \%)$. Crystals of $\left\{\left[\mathrm{HAlTp}^{\mathrm{Me}}{ }_{2}\right] \mathrm{Li}\right\}_{2}$ suitable for X-ray diffraction were obtained from a solution in benzene. ${ }^{1} \mathrm{H}$ NMR $\left(\mathrm{C}_{6} \mathrm{D}_{6}\right): \delta 1.61[\mathrm{~s}, 18 \mathrm{H}$ of $\left.\left\{\mathrm{HAl}\left\{\mathrm{HC}_{3} \mathrm{~N}_{2}\left(\mathrm{C}_{3}\right)_{2}\right\}_{2}\left\{\mathrm{HC}_{3} \mathrm{~N}_{2}\left(\mathrm{CH}_{3}\right)_{2}\right\} \mathrm{Li}\right\}_{2}\right], 2.48$ [s, $18 \mathrm{H}$ of $\left.\left\{\mathrm{HGa}\left\{\mathrm{HC}_{3} \mathrm{~N}_{2}\left(\mathrm{C}_{3}\right)_{2}\right\}_{2}\left\{\mathrm{HC}_{3} \mathrm{~N}_{2}\left(\mathrm{C}_{3}\right)_{2}\right\} \mathrm{Li}\right\}_{2}\right], 5.74[\mathrm{~s}, 6 \mathrm{H}$ of

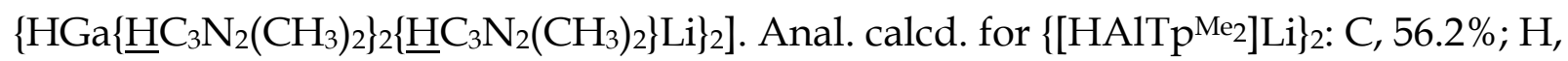
6.9\%; N, 26.2\%. Found: C, 56.1\%; H, 6.9\%; N, 26.0\%. IR (cm-1): $3198(w), 3130(w), 3106$ (w), $3032(\mathrm{w}), 2926(\mathrm{w}), 2872(\mathrm{w}), 1904(\mathrm{w}), 1541(\mathrm{~s}), 1415(\mathrm{~m}), 1315(\mathrm{~s}), 1127(\mathrm{~m}), 1026$ (m), 980 (w), 859 (br, w), 777 (m), 752 (m), 708 (w), $684(\mathrm{w}), 652$ (w), 591 (w), $519(\mathrm{~s}), 499$ $(\mathrm{s})$.

\section{Synthesis of $\left\{\left[\mathrm{HGaTp} \mathrm{Me}_{2}\right] \mathrm{Li}\right\}_{2}$}

A mixture of $\mathrm{LiGaH}_{4}(14.0 \mathrm{mg}, 0.17 \mathrm{mmol})$ and 3,5-dimethylpyrazole $(49.8 \mathrm{mg}, 0.52$ $\mathrm{mmol}$ ) in an NMR tube equipped with a J-Young valve was treated with $\mathrm{C}_{6} \mathrm{D}_{6}(c a .0 .7$ $\mathrm{mL}$ ). After heating the light gray reaction mixture at $80^{\circ} \mathrm{C}$ for 1 day, colorless crystals suitable for X-ray diffraction were deposited. The solution was decanted and the crystals were washed with pentane and dried in vacuo to yield $\left\{\left[\mathrm{HGaTp} \mathrm{Me}_{2}\right] \mathrm{Li}\right\}_{2}(21.3$ mg, 68\%). ${ }^{1} \mathrm{H}$ NMR $\left(\mathrm{C}_{6} \mathrm{D}_{6}\right): \delta 1.65$ [s, $18 \mathrm{H}$ of $\left.\left\{\mathrm{HGa}\left\{\mathrm{HC}_{3} \mathrm{~N}_{2}\left(\mathrm{C}_{3}\right)_{2}\right\}_{2}\left\{\mathrm{HC}_{3} \mathrm{~N}_{2}\left(\mathrm{C}_{3}\right)_{2}\right\} \mathrm{Li}\right\}_{2}\right]$, $2.36\left[\mathrm{~s}, 18 \mathrm{H}\right.$ of $\left.\left\{\mathrm{HGa}\left\{\mathrm{HC}_{3} \mathrm{~N}_{2}\left(\underline{\mathrm{C}}_{3}\right)_{2}\right\}_{2}\left\{\mathrm{HC}_{3} \mathrm{~N}_{2}\left(\mathrm{C}_{3}\right)_{2}\right\} \mathrm{Li}\right\}_{2}\right], 5.77$ [s, $6 \mathrm{H}$ of $\left.\left\{\mathrm{HGa}\left\{\underline{\mathrm{H} C} \mathrm{C}_{3} \mathrm{~N}_{2}\left(\mathrm{CH}_{3}\right)_{2}\right\}_{2}\left\{\underline{\mathrm{H}} \mathrm{C}_{3} \mathrm{~N}_{2}\left(\mathrm{CH}_{3}\right)_{2}\right\} \mathrm{Li}\right\}_{2}\right] .{ }^{7 \mathrm{Li}}\left\{{ }^{1} \mathrm{H}\right\} \mathrm{NMR}\left(\mathrm{C}_{6} \mathrm{D}_{6}\right): 2.93$ [s]. Anal. calcd. for $\left\{\left[\mathrm{HGaTp}^{\mathrm{Me}} 2\right] \mathrm{Li}\right\}_{2}: \mathrm{C}, 49.6 \% ; \mathrm{H}, 6.1 \% ; \mathrm{N}, 23.2 \%$. Found: C, 49.6\%; H, 6.2\%; N, 23.2\%. IR 
$\left(\mathrm{cm}^{-1}\right)$ : $3200(\mathrm{w}), 3131(\mathrm{w}), 3111(\mathrm{w}), 3038(\mathrm{w}), 2926(\mathrm{~m}), 2877(\mathrm{w}), 1980(\mathrm{~m}), 1530(\mathrm{~s}), 1420$ (s), $1323(\mathrm{~s}), 1024(\mathrm{~s}), 659$ (s).

\section{Synthesis of $\left\{\left[\mathrm{Tp}^{\mathrm{Me}}\right]_{\mathrm{Li}}\right\}_{2}{ }^{15 a}$}

A stirred mixture of 3,5-dimethylpyrazole $(1.96 \mathrm{~g}, 20.4 \mathrm{mmol})$ and $\mathrm{LiBH}_{4}(0.111 \mathrm{~g}, 5.1$ mmol) was heated at $c a .210^{\circ} \mathrm{C}$ until hydrogen evolution ceased. After this period, the mixture was cooled to room temperature and the solid was crushed in an inert atmosphere. Excess 3,5-dimethylpyrazole was removed by sublimation at approximately $160^{\circ} \mathrm{C}$ in vacuo to give $\left\{\left[\mathrm{Tp}^{\mathrm{Me}}\right] \mathrm{Li}_{2}\right.$ as a white powder $(978.5 \mathrm{mg}, 63 \%)$. Crystals suitable for X-ray diffraction were obtained from a solution in benzene. ${ }^{1} \mathrm{H}$ $\operatorname{NMR}\left(\mathrm{C}_{6} \mathrm{D}_{6}\right): \delta 1.74\left[\mathrm{~s}, 18 \mathrm{H}\right.$ of $\left.\left\{\mathrm{HB}\left\{\mathrm{HC}_{3} \mathrm{~N}_{2}\left(\mathrm{C}_{3}\right)_{2}\right\}_{2}\left\{\mathrm{HC}_{3} \mathrm{~N}_{2}\left(\mathrm{C}_{3}\right)_{2}\right\} \mathrm{Li}\right\}_{2}\right], 2.33$ [s, $18 \mathrm{H}$ of $\left.\left.\mathrm{HB}\left\{\mathrm{HC}_{3} \mathrm{~N}_{2}\left(\underline{\mathrm{C}}_{3}\right)_{2}\right\}_{2}\left\{\mathrm{HC}_{3} \mathrm{~N}_{2}\left(\mathrm{C}_{3}\right)_{2}\right\} \mathrm{Li}\right\}_{2}\right], 5.75$ [s, $6 \mathrm{H}$ of

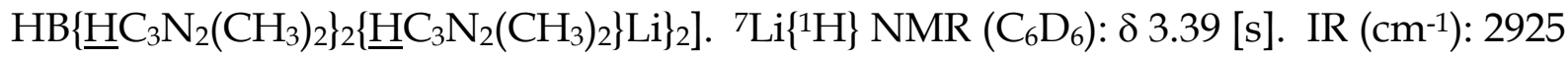
(w), 2498 (w) , 1547 (m), 1536 (m), 1439 (m), 1416 (m), 1375 (w), 1363 (m), 1344 (m), 1210 (w), 1195 (m), $1170(\mathrm{~s}), 1067$ (m), 1041 (m), 1032 (m), 981 (w), 832 (w), 803 (s), 773 (s), 709 $(\mathrm{w}), 644(\mathrm{~s})$. 
Table 8. Crystal, intensity collection, and refinement data.

\begin{tabular}{|c|c|c|c|c|}
\hline & $\begin{array}{c}{\left[\mathrm{HAlT} \mathbf{p}^{\left.\mathrm{Bu} \mathrm{u}^{\mathrm{t}} \mathrm{Me}\right] \mathrm{L}}\right.} \\
\mathbf{i}\end{array}$ & {$\left[\mathrm{HGaT} p^{\mathrm{Bu}}{ }^{\mathrm{t}} \mathrm{Me}\right] \mathrm{Li}$} & $\begin{array}{c}{\left[\left(\mathrm{pz}^{\left.\mathrm{Bu} \mathbf{t}^{\mathrm{t}} \mathrm{Me}\right)}\right) \mathrm{Al}-\right.} \\
\left.\mathrm{Tp}^{\mathrm{Bu}} \mathbf{u}^{\mathrm{t}}, \mathrm{Me}\right] \mathrm{Li}\end{array}$ & $\begin{array}{c}{\left[\left(\mathrm{pz}^{\mathrm{Bu}}{ }^{\mathrm{t}}, \mathrm{Me}\right)_{2} \mathrm{Al}-\right.} \\
\left.\mathrm{Bp}^{\mathrm{Bu}} \mathrm{u}^{\mathrm{t}} \mathrm{Me}\right] \mathrm{Li}- \\
(\mathrm{THF})\end{array}$ \\
\hline lattice & Monoclinic & Trigonal & Monoclinic & Monoclinic \\
\hline formula & $\mathrm{C}_{24} \mathrm{H}_{40} \mathrm{AlLiN}_{6}$ & $\mathrm{C}_{24} \mathrm{H}_{40} \mathrm{GaLiN}_{6}$ & $\mathrm{C}_{32} \mathrm{H}_{52} \mathrm{AlLiN}$ & $\mathrm{C}_{36} \mathrm{H}_{60} \mathrm{AlLiN}_{8}$ \\
\hline formula weight & 446.54 & 489.28 & 582.73 & $65 \overline{4} .84$ \\
\hline space group & $P 2_{1} / n$ & P-3 & $\mathrm{C} 2 / \mathrm{c}$ & $P 2_{1} / n$ \\
\hline$a / \AA$ & $9.4683(7)$ & $11.6814(4)$ & 27.6904(19) & $12.2404(9)$ \\
\hline$b / \AA$ & $30.767(2)$ & $11.6814(4)$ & 12.7791(9) & $16.2997(12)$ \\
\hline$c / \AA$ & $9.7095(7)$ & $11.9843(5)$ & $23.4991(16)$ & $20.1682(14)$ \\
\hline$\alpha /^{\circ}$ & 90 & 90 & 90 & 90 \\
\hline$\beta /^{\circ}$ & $106.6413(10)$ & 90 & $120.7018(9)$ & $99.4440(12)$ \\
\hline$\gamma /^{\circ}$ & 90 & 120 & 90 & 90 \\
\hline$V / \AA^{3}$ & $2710.1(3)$ & $1416.24(10)$ & $7149.8(9)$ & $3969.3(5)$ \\
\hline Z & 4 & 2 & 8 & 4 \\
\hline temperature $(\mathrm{K})$ & $160(2)$ & $170(2)$ & $160(2)$ & $160(2)$ \\
\hline radiation $(\lambda, \AA)$ & 0.71073 & 0.71073 & 0.71073 & 0.71073 \\
\hline$\rho$ (calcd.) $\mathrm{g} \mathrm{cm}^{-3}$ & 1.094 & 1.147 & 1.083 & 1.096 \\
\hline$\mu($ Mo K $\alpha), \mathrm{mm}^{-1}$ & 0.096 & 0.991 & 0.088 & 0.088 \\
\hline$\theta \max$, deg. & 30.525 & 30.634 & 30.544 & 30.620 \\
\hline no. of data & 44215 & 23530 & 57925 & 64715 \\
\hline $\begin{array}{l}\text { collected } \\
\text { no. of data }\end{array}$ & 8266 & 2925 & 10934 & 12187 \\
\hline no. of parameters & 318 & 104 & 420 & 441 \\
\hline$R_{1}[I>2 \sigma(I)]$ & 0.0506 & 0.0325 & 0.0498 & 0.0746 \\
\hline$w R_{2}[I>2 \sigma(I)]$ & 0.1368 & 0.0771 & 0.1492 & 0.1747 \\
\hline$R_{1}$ [all data] & 0.0752 & 0.0395 & 0.0648 & 0.1759 \\
\hline$w R_{2}$ [all data] & 0.1493 & 0.0799 & 0.1589 & 0.2237 \\
\hline GOF & 1.315 & 0.996 & 1.448 & 1.037 \\
\hline$R_{i n t}$ & 0.0671 & 0.0856 & 0.0417 & 0.1625 \\
\hline
\end{tabular}


Table 8. (cont.)

\begin{tabular}{|c|c|c|c|}
\hline & $\left\{\left[\mathrm{HAlTp} \mathrm{pe}_{2}\right] \mathrm{Li}\right\}_{2}$ & $\left\{\left[\mathrm{HGaTp} \mathrm{Me}_{2}\right] \mathrm{Li}\right\}_{2}$ & $\left\{\left[\mathrm{Tp}^{\mathrm{Me}} \mathrm{e}_{2}\right] \mathrm{Li}\right\}_{2} \cdot 2 \mathrm{C}_{6} \mathrm{H}_{6}$ \\
\hline lattice & Triclinic & Triclinic & Monoclinic \\
\hline formula & $\mathrm{C}_{30} \mathrm{H}_{44} \mathrm{Al}_{2} \mathrm{Li}_{2} \mathrm{~N}_{12}$ & $\mathrm{C}_{30} \mathrm{H}_{44} \mathrm{Ga}_{2} \mathrm{Li}_{2} \mathrm{~N}_{12}$ & $\mathrm{C}_{42} \mathrm{H}_{56} \mathrm{~B}_{2} \mathrm{Li}_{2} \mathrm{~N}_{12}$ \\
\hline formula weight & 640.61 & 726.09 & 764.48 \\
\hline space group & $P-1$ & $P-1$ & $P 21 / c$ \\
\hline$a / \AA$ & $8.9870(8)$ & $9.0077(5)$ & $9.8173(6)$ \\
\hline$b / \AA$ & $10.1250(9)$ & $10.1071(5)$ & 25.9503(15) \\
\hline$c / \AA$ & $10.9118(10)$ & $10.8625(6)$ & $8.6622(5)$ \\
\hline$\alpha /^{\circ}$ & 66.1554(12) & $66.4875(7)$ & 90 \\
\hline$\beta /^{\circ}$ & 77.3727(13) & 77.3019(7) & $98.1248(10)$ \\
\hline$\gamma /{ }^{\circ}$ & $77.4116(13)$ & $77.3943(7)$ & 90 \\
\hline$V / \AA^{3}$ & $876.80(14)$ & $875.18(8)$ & $2184.6(2)$ \\
\hline Z & 1 & 1 & 2 \\
\hline temperature (K) & $160(2)$ & $160(2)$ & $160(2)$ \\
\hline radiation $(\lambda, \AA)$ & 0.71073 & 0.71073 & 0.71073 \\
\hline$\rho$ (calcd.) $\mathrm{g} \mathrm{cm}^{-3}$ & 1.213 & 1.378 & 1.162 \\
\hline$\mu(\mathrm{Mo} \mathrm{K \alpha}), \mathrm{mm}^{-1}$ & 0.122 & 1.578 & 0.071 \\
\hline$\theta$ max, deg. & 30.581 & 30.691 & 30.625 \\
\hline $\begin{array}{l}\text { no. of data } \\
\text { collected }\end{array}$ & 14432 & 14374 & 35759 \\
\hline no. of data & 5340 & 5378 & 6717 \\
\hline no. of parameters & 218 & 218 & 273 \\
\hline$R_{1}[I>2 \sigma(I)]$ & 0.0441 & 0.0382 & 0.0606 \\
\hline$w R_{2}[I>2 \sigma(I)]$ & 0.1443 & 0.1061 & 0.1406 \\
\hline$R_{1}$ [all data] & 0.0536 & 0.0430 & 0.1163 \\
\hline$w R_{2}$ [all data] & 0.1514 & 0.1092 & 0.1657 \\
\hline GOF & 1.472 & 1.087 & 1.085 \\
\hline$R_{\text {int }}$ & 0.0376 & 0.0545 & 0.1164 \\
\hline
\end{tabular}

Acknowledgements. We thank the National Science Foundation (CHE-1465095) for support of this research. 


\section{APPENDIX A. Supplementary Data}

Tables of computational data for the geometry optimized structures and crystallographic data in CIF format (CCDC \#1503727-1503733). These data can be obtained free of charge via http://www.ccdc.cam.ac.uk/conts/retrieving.html, or from the Cambridge Crystallographic Data Centre, 12 Union Road, Cambridge CB2 1EZ, UK; fax: (+44) 1223-336-033; or e-mail: deposit@ccdc.cam.ac.uk. Supplementary data associated with this article can be found, in the online version, at doi:10.1016/j.poly.xxxxxx. 


\section{REFERENCES}

(1) Trofimenko, S. J. Am. Chem. Soc. 1966, 88, 1842-1844.

(2) (a) Scorpionates - The Coordination Chemistry of Polypyrazolylborate Ligands, S. Trofimenko, Imperial College Press, London, 1999.

(b) Scorpionates II: Chelating Borate Ligands, C. Pettinari, Imperial College Press, London, 2008.

(c) Parkin, G. Chem. Rev. 2004, 104, 699-767.

(d) Parkin, G. Chem. Commun. 2000, 1971-1985.

(e) Parkin, G. Met. Ions Biol. Syst., Vol. 38, Chapter 14, pp 411-460; A. Sigel and H. Sigel, eds., M. Dekker, New York, 2001.

(f) Parkin, G. Adv. Inorg. Chem. 1995, 42, 291-393.

(g) Santini, C.; Pellei, M.; Lobbia, G. G.; Papini, G. Mini-Rev. Org. Chem. 2010, 7, 84-124.

(h) Kitajima, N.; Tolman, W. B. Prog. Inorg. Chem. 1995, 43, 419-531.

(i) Trofimenko, S. Polyhedron 2004, 23, 197-203.

(3) (a) Han, R.; Parkin, G. Inorg. Chem. 1993, 32, 4968-4970.

(b) Han, R.; Parkin, G. Inorg. Chem. 1992, 31, 983-988.

(4) (a) Han, R.; Parkin, G. J. Am. Chem. Soc. 1992, 114, 748-757.

(b) Han, R.; Looney, A.; Parkin, G. J. Amer. Chem. Soc. 1989, 111, 7276-7278.

(c) Han, R.; Parkin, G. J. Organomet. Chem. 1990, 393, C43-C46.

(d) Han, R.; Parkin, G. Polyhedron 1990, 9, 2655-2657.

(e) Han, R.; Parkin, G. Organometallics 1991, 10, 1010-1020.

(f) Ghosh, P.; Parkin, G. Polyhedron 1997, 16, 1255-1257.

(5) Rauch, M.; Ruccolo, S.; Mester, J. P.; Rong, Y.; Parkin, G. Chem. Sci. 2016, 7, 142149.

(6) (a) Gorrell, I. B.; Looney, A.; Parkin, G. J. Chem. Soc., Chem. Commun. 1990, 220222. 
(b) Han, R.; Gorrell, I. B.; Looney, A. G.; Parkin, G. J. Chem. Soc., Chem. Commun. 1991, 717-719.

(c) Looney, A.; Han, R.; Gorrell, I. B.; Cornebise, M.; Yoon, K.; Parkin, G.;

Rheingold, A. L. Organometallics 1995, 14, 274-288.

(d) Kisko, J. L.; Fillebeen, T.; Hascall, T.; Parkin, G. J. Organomet. Chem. 2000, $596,22-26$.

(e) Yoon, K.; Parkin, G. J. Am. Chem. Soc. 1991, 113, 8414-8418.

(7) (a) Looney, A.; Han, R.; McNeill, K.; Parkin, G. J. Am. Chem. Soc. 1993, 115, 46904697.

(b) Alsfasser, R.; Trofimenko, S.; Looney, A.; Parkin, G.; Vahrenkamp, H. Inorg. Chem. 1991, 30, 4098-4100.

(c) Looney, A.; Parkin, G.; Alsfasser, R.; Ruf, M.; Vahrenkamp, H. Angew. Chem. Int. Edit. Engl. 1992, 31, 92-93.

(d) Sattler, W.; Parkin, G. Chem.Sci. 2012, 3, 2015-2019.

(e) Sattler, W.; Parkin, G. Polyhedron 2012, 32, 41-48.

(f) Rauch, M.; Rong, Y.; Sattler, W.; Parkin, G. Polyhedron 2016, 103, 135-140.

(8) Looney, A.; Saleh, A.; Zhang, Y.; Parkin, G. Inorg. Chem. 1994, 33, 1158-1164.

(9) (a) Kuchta, M. C.; Bonanno, J. B.; Parkin, G. J. Am. Chem. Soc. 1996, 118, 1091410915.

(b) Kuchta, M. C.; Parkin, G. J. Chem. Soc. Dalton Trans. 1998, 2279-2280.

(c) Kuchta, M. C.; Parkin, G. Inorg. Chem. 1997, 36, 2492-2493.

(10) (a) Kuchta, M. C.; Dias, H. V. R.; Bott, S. G.; Parkin, G. Inorg. Chem. 1996, 35, 2708-2708.

(b) Kuchta, M. C.; Dias, H. V. R.; Bott, S. G.; Parkin, G. Inorg. Chem. 1996, 35, $943-$ 948.

(c) Kuchta, M. C.; Parkin, G. J. Am. Chem. Soc. 1995, 117, 12651-12652. 
(11) Searches of the Cambridge Structural Database were performed with version 5.37. See: Groom, C. R.; Bruno, I. J.; Lightfoot, M. P.; Ward, S. C. Acta Cryst. 2016, B72, 171-179.

(12) Snyder, C. J.; Heeg, M. J.; Winter, C. H. Inorg. Chem. 2011, 9210-9212.

(13) Alkyl substituted $\left[R A l T p^{R, R^{\prime}}\right]$ and $\left[R G a T p^{R, R^{\prime}}\right]$ derivatives have, nevertheless, been reported. See:

(a) Muñoz-Hernández, M. A.; Montiel-Palma, V. Inorg. Chim. Acta 2009, 362, 4328-4339.

(b) Cortes-Llamas, S. A.; Muñoz-Hernandez, M. A. Organometallics 2007, 26, 6844-6851.

(c) Cortes-Llamas, S.; Velázquez-Carmona, M. A.; Muñoz-Hernandez, M. A. Inorg. Chem. Commun. 2005, 8, 155-158.

(d) Breakell, K. R.; Rettig, S. J.; Singbeil, D. L.; Storr, A.; Trotter, J. Can. J. Chem. 1978, 56, 2099-2108.

(14) The tetrakis(pyrazolyl)aluminate compound, [Alpz4] $\mathrm{Na}$, has also been reported. However, the compound was not obtained via the reaction of pyrazole with $\mathrm{NaAlH}_{4}$, but rather via the reaction of Napz with $\mathrm{Et}_{3} \mathrm{Al}$, followed by addition of pzH. See: Breakell, K. R.; Patmore, D. J.; Storr, A. J. Chem. Soc. Dalton Trans. $1975,749-754$.

(15) It is worth noting that these reactions of $\mathrm{LiAlH}_{4}$ and $\mathrm{LiGaH}_{4}$ to form $\left[\right.$ HETp $\left.\mathrm{p}^{\mathrm{R}, \mathrm{Me}}\right] \mathrm{Li}$ occur at lower temperatures than those employed for the synthesis of alkali metal $\left[\mathrm{Tp}^{\mathrm{R}, \mathrm{R}^{\prime}}\right] \mathrm{M}$ derivatives. See, for example:

(a) Trofimenko, S. J. Am. Chem. Soc. 1967, 89, 6288-6294.

(b) Trofimenko, S.; Calabrese, J. C.; Kochi, J. K.; Wolowiec, S.; Hulsbergen, F. B.; Reedijk, J. Inorg. Chem. 1992, 31, 3943-3950.

(16) Note that "trigonal pyramidal" is not synonymous with "trigonal monopyramidal" since the latter refers to four-coordinate geometries. See, for 
example:

(a) Chakrabarti, N.; Sattler, W.; Parkin, G. Polyhedron 2013, 58, 235-246.

(b) Dean, P. A. W.; Vittal, J. J.; Payne, N. C. Inorg. Chem. 1984, 23, 4232-4236.

(c) Izod, K.; Stewart, J.; Clark, E. R.; McFarlane, W.; Allen, B.; Clegg, W.;

Harrington, R. W. Organometallics 2009, 28, 3327-3337.

(d) Yamana, S. J. Chem. Educ. 1988, 65, 1074-1074.

(e) Cummins, C. C.; Lee, J.; Schrock, R. R.; Davis, W. D. Angew. Chem. Int. Edit. Engl. 1992, 31, 1501-1503.

(f) Ray, M.; Hammes, B. S.; Yap, G. P. A.; Rheingold, A. L.; Borovik, A. S. Inorg. Chem. 1998, 37, 1527-1532.

(g) Searls, C. E.; Kleespies, S. T.; Eppright, M. L.; Schwartz, S. C.; Yap, G. P. A.; Scarrow, R. C. Inorg. Chem. 2010, 49, 11261-11263.

(h) Kuiper, D. S.; Douthwaite, R. E.; Mayol, A. R.; Wolczanski, P. T.; Lobkovsky, E. B.; Cundari, T. R.; Lam, O. P.; Meyer, K. Inorg. Chem. 2008, 47, 7139-7153.

(i) Suzuki, S.; Sakurai, T.; Nakahara, A.; Masuko, M.; Iwasaki, H. Biochimica et Biophysica Acta 1985, 827, 190-192.

(j) Schumann, H.; Hartmann, U.; Dietrich, A.; Pickardt, J. Angew. Chem. Int. Edit. Engl. 1988, 27, 1077-1078.

(17) For some examples of lithium in a trigonal coordination environment, see reference $16 \mathrm{a}$ and:

(a) Kisko, J. L.; Hascall, T.; Kimblin, C.; Parkin, G. J. Chem. Soc. Dalton Trans. 1999, 1929-1935.

(b) Brauer, D. J.; Burger, H.; Liewald, G. R.; Wilke, J. J. Organomet. Chem. 1985, $287,305-320$.

(c) Campbell, R.; Garcia-Alvarez, P.; Kennedy, A. R.; Mulvey, R. E. Chem.-Eur. J. 2010, 16, 9964-9968. 
(18) It should, however, be noted that the protonated species, $\mathrm{H}\left[\left(\mathrm{pz}^{\mathrm{Me} 2}\right) \mathrm{T} \mathrm{p}^{\mathrm{Me}} 2\right]$, has been obtained. See: Bradley, D. C.; Hursthouse, M. B.; Newton, J.; Walker, N. P. C. J. Chem. Soc. Chem. Commun. 1984, 188-190.

(19) For other examples of fluxionality involving pyrazolyl group exchange in $\left[\mathrm{B}\left(\mathrm{pz}^{\mathrm{R}, \mathrm{R}^{\prime}}\right)_{4}\right]$ derivatives, see:

(a) Trofimenko, S. J. Am. Chem. Soc. 1969, 91, 3183-3189.

(b) Onishi, M.; Kayano, K. H.; Inada, K.; Yamaguchi, H.; Nagaoka, J.; Arikawa, Y.; Takatani, T. Inorg. Chim. Acta 2004, 357, 4091-4101.

(c) Manzer, L. E.; Meakin, P. Z. Inorg. Chem. 1976, 15, 3117-3120.

(d) Onishi, M.; Hiraki, K.; Shironita, M.; Yamaguchi, Y.; Nakagawa, S. Bull.

Chem. Soc. Jpn. 1980, 53, 961-967.

(e) Onishi, M.; Yamaguchi, M.; Nishimoto, E.; Itoh, Y.; Nagaoka, J.; Umakoshi, K.; Kawano, H. Inorg. Chim. Acta 2003, 343, 111-118.

(f) Cocivera, M.; Desmond, T. J.; Ferguson, G.; Kaitner, B.; Lalor, F. J.; O'Sullivan, D. J. Organometallics 1982, 1, 1125-1132.

(g) Reger, D. L.; Knox, S. J.; Huff, M. F.; Rheingold, A. L.; Haggerty, B. S. Inorg. Chem. 1991, 30, 1754-1759.

(h) Reger, D. L.; Huff, M. F.; Rheingold, A. L.; Haggerty, B. S. J. Am. Chem. Soc. 1992, 114, 579-584.

(i) Chisholm, M. H.; Gallucci, J. C.; Yaman, G. Inorg. Chem. 2007, 46, 8676-8683.

(j) Abu Salah, O. M.; Bruce, M. I.; Lohmeyer, P. J.; Raston, C. L.; Skelton, B. W.; White, A. H. J. Chem. Soc. Dalton Trans. 1981, 962-967.

(k) Cocivera, M.; Ferguson, G.; Lalor, F. J.; Szczecinski, P. Organometallics 1982, 1, 1139-1142.

(l) Onishi, M.; Hiraki, K.; Ueno, A.; Yamaguchi, Y.; Ohama, Y. Inorg. Chim. Acta $1984,82,121-124$. 
(m) Ohkita, K.; Kurosawa, H.; Hasegawa, T.; Shirafuji, T.; Ikeda, I. Inorg. Chim. Acta 1992, 198-200, 275-282.

(20) For examples of compounds that feature alkali metal-arene interactions, see: (a) Dowling, C. M.; Leslie, D.; Chisholm, M. H.; Parkin, G. Main Group Chem. 1995, 1, 29-52.

(b) Hellmann, K. W.; Galka, C.; Gade, L. H.; Steiner, A.; Wright, D. S.; Kottke, T.; Stalke, D. Chem. Commun. 1998, 549-550.

(c) Fedushkin, I. L.; Lukoyanov, A. N.; Hummert, M.; Schumann, H. Russ. Chem. Bull. 2007, 56, 1765-1770.

(d) Mahadevi, A. S.; Sastry, G. N. Chem. Rev. 2013, 113, 2100-2138.

(e) Amicangelo, J. C.; Armentrout, P. B. J. Phys. Chem. A 2000, 104, 11420-11432.

(f) Fedushkin, I. L.; Lukoyanov, A. N.; Hummert, M.; Schumann, H. Russ. Chem. Bull. 2007, 56, 1765-1770.

(g) Bertermann, R.; Braunschweig, H.; Constantinidis, P.; Dellermann, T.;

Dewhurst, R. D.; Ewing, W. C.; Fischer, I.; Kramer, T.; Mies, J.; Phukan, A. K.; Vargas, A. Angew. Chem. Int. Edit. 2015, 54, 13090-13094.

(21) Cordero, B.; Gómez, V.; Platero-Prats, A. E.; Revés, M.; Echeverría, J.; Cremades, E.; Barragán, F.; Alvarez, S. Dalton Trans. 2008, 2832-2838.

(22) (a) Pyykkö, P.; Atsumi, M. Chem. Eur. J. 2009, 15, 186-197.

(b) Pyykkö, P. J. Phys. Chem. (A) 2015, 119, 2326-2337.

(23) Ths scandide contraction is also referred to as the d-block contraction. See, for example:

(a) Wulfsberg, G. Inorganic Chemistry, University Science Books, Sausalito, California, 2000, p. 35.

(b) King, R. B. (Ed.), Encyclopedia of Inorganic Chemistry, Vol. 4, Wiley, New York, 1994, p. 1943.

(24) Dowling, C. M.; Parkin, G. Polyhedron 1999, 18, 3567-3571. 
(25) $\tau_{4}=[360-(\alpha+\beta)] / 141$, where $\alpha$ and $\beta$ are the two largest angles. $\tau_{4 \delta}=$ $\tau_{4}(\alpha / \beta) \square \square \square \square \square \square \square \alpha>\beta$. See:

(a) Yang, L.; Powell, D. R.; Houser, R. P. Dalton Trans. 2007, 955-964.

(b) Reineke, M. H.; Sampson, M. D.; Rheingold, A. L.; Kubiak, C. P. Inorg. Chem. 2015, 54, 3211-3217.

(26) Guo, S. L.; Peters, F.; de Biani, F. F.; Bats, J. W.; Herdtweck, E.; Zanello, P.; Wagner, M. Inorg. Chem. 2001, 40, 4928-4936.

(27) Mealli, C.; Arcus, C. S.; Wilkinson, J. L.; Marks, T. J.; Ibers, J. A. J. Am. Chem. Soc. 1976, 98, 711-718.

(28) (a) McNally, J. P.; Leong, V. S.; Cooper, N. J. in Experimental Organometallic Chemistry, Wayda, A. L.; Darensbourg, M. Y., Eds.; American Chemical Society: Washington, DC, 1987; Chapter 2, pp 6-23.

(b) Burger, B.J.; Bercaw, J. E. in Experimental Organometallic Chemistry; Wayda, A. L.; Darensbourg, M. Y., Eds.; American Chemical Society: Washington, DC, 1987; Chapter 4, pp 79-98.

(c) Shriver, D. F.; Drezdzon, M. A.; The Manipulation of Air-Sensitive Compounds, $2^{\text {nd }}$ Edition; Wiley-Interscience: New York, 1986.

(29) Fulmer, G. R.; Miller, A. J. M.; Sherden, N. H.; Gottlieb, H. E.; Nudelman, A.; Stoltz, B. M.; Bercaw, J. E.; Goldberg, K. I. Organometallics 2010, 29, 2176-2179.

(30) Günther, H. Enc. Mag. Res. (2007) DOI: 10.1002/9780470034590.emrstm0273.

(31) (a) Harris, R. K.; Becker, E. D.; De Menezes, S. M. C.; Goodfellow, R.; Granger, P. Pure Appl. Chem. 2001, 73, 1795-1818.

(b) Harris, R. K.; Becker, E. D.; De Menezes, S. M. C.; Granger, P.; Hoffman, R. E.; Zilm, K. W. Pure Appl. Chem. 2008, 80, 59-84.

(32) Ammann, C.; Meier, P.; Merbach, A. E. J. Magn. Reson. 1982, 46, 319-321.

(33) Budzelaar, P. H. M. gNMR Version 5.0.1.0, 2002, Ivory Soft.

(34) Shirk, A. E.; Shriver, D. F. Inorganic Syntheses. 1977, 17, 45-47. 
(35) (a) Sheldrick, G. M. SHELXTL, An Integrated System for Solving, Refining, and Displaying Crystal Structures from Diffraction Data; University of Göttingen, Göttingen, Federal Republic of Germany, 1981.

(b) Sheldrick, G. M. Acta Cryst. 2008, A64, 112-122.

(36) (a) Jaguar, version 8.9, Schrodinger, Inc., New York, NY, 2015.

(b) Bochevarov, A. D.; Harder, E.; Hughes, T. F.; Greenwood, J. R.; Braden, D. A.; Philipp, D. M.; Rinaldo, D.; Halls, M. D.; Zhang, J.; Friesner, R. A. Int. J. Quantum Chem. 2013, 113, 2110-2142.

(37) Jaguar 7.7, Schrödinger, LLC, New York, NY 2010.

(38) (a) Becke, A. D. J. Chem. Phys. 1993, 98, 5648-5652.

(b) Becke, A. D. Phys. Rev. A 1988, 38, 3098-3100.

(c) Lee, C. T.; Yang, W. T.; Parr, R. G. Phys. Rev. B 1988, 37, 785-789.

(d) Vosko, S. H.; Wilk, L.; Nusair, M. Can. J. Phys. 1980, 58, 1200-1211.

(e) Slater, J. C. Quantum Theory of Molecules and Solids, Vol. 4: The Self-Consistent

Field for Molecules and Solids; McGraw-Hill: New York, 1974. 


\section{Graphical Abstract}

Tris(pyrazolyl)hydroaluminate derivatives, [HAlTp $\left.{ }^{\mathrm{Bu}^{\mathrm{t}}, \mathrm{Me}}\right] \mathrm{Li}$ and $\left\{\left[\mathrm{HAlTp}^{\mathrm{Me}}\right] \mathrm{Li}_{2}\right.$, have been synthesized via the reactions of $\mathrm{LiAlH}_{4}$ with 3-tert-butyl-5-methylpyrazole and 3,5dimethylpyrazole, respectively, while the tris(pyrazolyl)hydrogallate counterparts, $\left[\mathrm{HGaTp}^{\mathrm{Bu}, \mathrm{Me}}\right] \mathrm{Li}$ and $\left\{\left[\mathrm{HGaTp}^{\mathrm{Me}}\right] \mathrm{Li}_{2}\right.$, are obtained from the corresponding reactions with $\mathrm{LiGaH}_{4}$. 